\title{
Elucidation of Molecular Mechanisms of Streptozotocin-Induced Oxidative Stress, Apoptosis, and Mitochondrial Dysfunction in Rin-5F Pancreatic $\beta$-Cells
}

\author{
Arwa M. T. Al Nahdi, Annie John, and Haider Raza \\ Department of Biochemistry, College of Medicine and Health Sciences (CMHS), UAE University, Al Ain, UAE \\ Correspondence should be addressed to Haider Raza; h.raza@uaeu.ac.ae
}

Received 26 April 2017; Revised 12 June 2017; Accepted 2 July 2017; Published 6 August 2017

Academic Editor: Maik Hüttemann

Copyright (c) 2017 Arwa M. T. Al Nahdi et al. This is an open access article distributed under the Creative Commons Attribution License, which permits unrestricted use, distribution, and reproduction in any medium, provided the original work is properly cited.

\begin{abstract}
Streptozotocin is a pancreatic beta-cell-specific cytotoxin and is widely used to induce experimental type 1 diabetes in rodent models. The precise molecular mechanism of STZ cytotoxicity is however not clear. Studies have suggested that STZ is preferably absorbed by insulin-secreting $\beta$-cells and induces cytotoxicity by producing reactive oxygen species/reactive nitrogen species (ROS/RNS). In the present study, we have investigated the mechanism of cytotoxicity of STZ in insulin-secreting pancreatic cancer cells (Rin-5F) at different doses and time intervals. Cell viability, apoptosis, oxidative stress, and mitochondrial bioenergetics were studied. Our results showed that STZ induces alterations in glutathione homeostasis and inhibited the activities of the respiratory enzymes, resulting in inhibition of ATP synthesis. Apoptosis was observed in a dose- and timedependent manner. Western blot analysis has also confirmed altered expression of oxidative stress markers (e.g., NOS and Nrf2), cell signaling kinases, apoptotic protein-like caspase-3, PARP, and mitochondrial specific proteins. These results suggest that STZ-induced cytotoxicity in pancreatic cells is mediated by an increase in oxidative stress, alterations in cellular metabolism, and mitochondrial dysfunction. This study may be significant in better understanding the mechanism of STZ-induced $\beta$-cell toxicity/resistance and the etiology of type 1 diabetes induction.
\end{abstract}

\section{Introduction}

Streptozotocin (STZ), [N-(methylnitrosocarbamoyl)- $\alpha$-Dglucosamine], is a broad spectrum antibiotic derived from the bacterium Streptomyces achromogenes [1]. It is a DNA alkylating agent and is often used as an antibacterial as well as anticancer agent $[2,3]$. However, it is not a preferred drug for the treatment of cancers. This is due to genotoxic effects which lead to drug resistance [4]. STZ is known to be a pancreatic beta-cell-specific cytotoxin and is therefore being widely used to induce experimental type 1 diabetes in rodent models $[5,6]$.

STZ is a glucose analogue that is selectively accumulated in pancreatic beta-cells via a GLUT 2 glucose transporter in the plasma membrane $[7,8]$. STZ toxicity in beta-cells is dependent on GLUT 2 expression. Hosokawa and his colleagues revealed that in transgenic mice, GLUT 2-expressing beta-cells are sensitive to the toxic effects of STZ whereas GLUT 1-expressing islets are completely resistant [9]. After entering the beta-cells via the GLUT 2 transporter, it causes DNA damage due to the DNA alkylating activity of its methyl nitrosourea moiety $[10,11]$, which, in turn, results in DNA fragmentation [12]. Subsequently, the fragmented DNA activates poly (ADP-ribose) synthetase to repair DNA. Poly ADP-ribosylation leads to the depletion of cellular NAD+ and ATP $[12,13]$. The decreased ATP synthesis is demonstrated by dephosphorylation which provides more substrates for xanthine oxidase, resulting in the formation of hydrogen peroxide and hydroxyl radicals $[14,15]$ causing oxidative stress. Furthermore, the presence of N-methyl-Nnitrosourea side chain has the ability to release nitric oxide $[16,17]$ that inhibits aconitase activity, resulting in mitochondrial dysfunction. STZ is diabetogenic due to its targeted GLUT 2-dependent action in the pancreatic $\beta$-cells. The 
exact mechanism of cytotoxicity is still not clear. However, both apoptotic and necrotic cell deaths of $\beta$-cells have been reported. The cytotoxicity of STZ is presumed to be mediated by reactive oxygen species (ROS), reactive nitric oxide species (NO/RNS), and induction of inflammatory responses $[16,17]$. Using both in vitro cell culture and in vivo diabetic rodent models for STZ-induced toxicity, we have demonstrated that STZ induces cellular oxidative stress and mitochondrial respiratory dysfunction [18-20].

In the present study, we have further investigated the mechanism of STZ cytotoxicity on insulin-secreting Rin-5F cells. Our results demonstrate that the effects of STZ are dose and time dependent, causing oxidative stress-associated alterations in GSH redox metabolism and mitochondrial respiratory dysfunction leading to increased apoptosis in Rin-5F cells. We have also identified some of the key apoptotic and oxidative stress molecular markers which exhibit altered expression in STZ-treated Rin-5F cells. In addition, we have also demonstrated that STZ treatment has induced the activities of CYP1A2 and CYP1A1 suggesting their potential role in STZ metabolism. These results may be significant in understanding the mechanism of STZinduced $\beta$-cell cytotoxicity/apoptosis and the ability of pancreatic cells to metabolize other xenobiotics in oxidative stress conditions.

\section{Materials and Methods}

2.1. Materials. Streptozotocin (STZ), reduced and oxidized glutathione (GSH/GSSG), 1-chloro 2,4-dinitrobenzene (CDNB), cumene hydroperoxide, glutathione reductase, 3(4,5-dimethylthiazol-2-yl)-2,5-diphenyltetrazolium bromide (MTT), NADH, NADPH, cytochrome c, coenzyme Q2, sodium succinate, antimycin A, dodecyl maltoside, resorufin, 7-ethoxyresorufin, methoxyresorufin, Hoechst 33342, and ATP bioluminescent somatic cell assay kits were purchased from Sigma-Aldrich (St. Louis, MO, USA). 2',7'-Dichlorofluorescein diacetate (DCFDA) was procured from molecular probes (Eugene, OR, USA). Kits for nitric oxide and caspase3 and caspase- 9 assays were purchased from R\&D Systems Inc., MN, USA, and that for lipid peroxidation (LPO) from Oxis International Inc. (CA, USA). Kits for GSH/GSSG assay were procured from Promega Corp. (Madison, WI, USA). Apoptosis detection kits for flow cytometry were purchased from BD Pharmingen (BD Biosciences, San Jose, USA). Rin-5F cells were obtained from American Type Culture Collection (Manassas, VA, USA). Polyclonal antibodies against beta-actin, caspase-3, PARP, NOS-2, Nrf2, GLUT 2, Bax, Bcl-2, Akt, and p-Akt were purchased from Santa Cruz Biotechnology Inc. (Santa Cruz, CA, USA). Reagents for cell culture, SDS-PAGE, and Western blot analyses were purchased from Gibco BRL (Grand Island, NY, USA) and Bio-Rad Laboratories (Richmond, CA, USA).

2.2. Cell Culture and Treatment. Rin-5F cells were grown in poly-L-lysine-coated $75 \mathrm{~cm}^{2}$ flasks $\left(\sim 2.0-2.5 \times 10^{6}\right.$ cells $\left./ \mathrm{mL}\right)$ in RPMI1640 medium supplemented with $1 \%$ nonessential amino acids, $2 \mathrm{mM}$ glutamine, and $10 \%$ heat-inactivated fetal bovine serum in a humidified incubator in the presence of
$5 \%-95 \% \mathrm{CO}_{2}$ air at $37^{\circ} \mathrm{C}$. Cells were treated with different concentrations of STZ (0-10 mM) dissolved in citrate buffer, $\mathrm{pH} 4.4$, and diluted in RPMI1640 to appropriate concentrations just before use for different time intervals ( $24 \mathrm{~h}-48 \mathrm{~h})$. Control cells were treated with vehicle alone. Concentrations and time points for STZ treatment in this study were based on MTT cytotoxicity tests and previously published reports $[18,21]$. After the desired time of treatment, cells were harvested, washed with PBS ( $\mathrm{pH} 7.4$ ), and homogenized in $\mathrm{H}$-medium buffer $(70 \mathrm{mM}$ sucrose, $220 \mathrm{mM}$ mannitol, $2.5 \mathrm{mM}$ HEPES, $2 \mathrm{mM}$ EDTA, and $0.1 \mathrm{mM}$ phenylmethylsulfonylfluoride, $\mathrm{pH} 7.4)$ at $4^{\circ} \mathrm{C}$. Mitochondrial and postmitochondrial fractions were then isolated by differential centrifugation. Cellular fractionation to prepare mitochondria fractions was performed by centrifugation, and the purity of the isolated fractions for cross contaminations was checked as described previously [20]. Protein concentration was determined by the Bradford method [22].

2.3. MTT Cell Viability Test. Mitochondrial dehydrogenasebased cell viability test in 96 -well plates $\left(\sim 2 \times 10^{4}\right.$ cells/well $)$ was assayed by MTT conversion to formazan after treatment with different concentrations $(0-10 \mathrm{mM})$ of STZ for different time intervals $(24 \mathrm{~h}-48 \mathrm{~h})$. The viable cells were quantitated using an ELISA reader (Anthos Laboratories, Salzburg, Germany) at $550 \mathrm{~nm}$ after subtracting the appropriate control value.

2.4. Measurement of Reactive Oxygen Species (ROS), NO, and $L P O$. Intracellular production of reactive oxygen species was measured using the cell permeable probe, DCFDA. Briefly, STZ-treated and control cells $\left(\sim 1 \times 10^{5}\right.$ cells $\left./ \mathrm{mL}\right)$ were grown on cover slips and incubated with $5 \mu \mathrm{M}$ DCFDA for $30 \mathrm{~min}$ at $37^{\circ} \mathrm{C}$. Cells were washed twice with PBS, and fluorescence was immediately visualized using the Olympus fluorescence microscope. DCFDA-based ROS assay was also performed and measured fluorimetrically as described before [18].

For NO assay, Rin-5F cells $\left(2 \times 10^{5}\right.$ cells/well $)$ were cultured in petri plates for $24 \mathrm{~h}$ prior to STZ treatments. $\mathrm{NO}$ production was determined by measuring the concentration of total nitrite in the culture supernatants using Griess reagent ( $R \& D$ Systems Inc.).

LPO in the cell extracts of STZ-treated and control Rin-5F cells was measured using the LPO-586 kit according to the manufacturer's recommended protocol and the concentration of MDA calculated from the standard curve.

\subsection{Apoptosis Measurement after STZ Treatments}

2.5.1. Nuclear Staining with Hoechst33342. Apoptosis measurement was performed by Hoechst dye staining of fragmented nuclei. Cover slips with adherent cells were treated with STZ, and cells were fixed with $3.7 \%$ formaldehyde and stained with Hoechst33342 $(10 \mu \mathrm{g} / \mathrm{mL})$ for $20 \mathrm{~min}$ at room temperature. The cover slips were washed, mounted on glass slides, and analyzed by fluorescence microscopy. Cells with signs of apoptosis showed fragmented nuclei.

2.5.2. Flow Cytometry. The apoptosis assay using flow cytometry was performed according to the vendor's protocol (BD 
Pharmingen, BD Biosciences, San Jose, USA) as described before [23]. Briefly, treated and control untreated cells were trypsinized, washed in PBS, and resuspended $\left(1 \times 10^{6}\right.$ cells/ $\mathrm{mL}$ ) in binding buffer (10 mM HEPES, pH 7.4, $140 \mathrm{mM}$ $\left.\mathrm{NaCl}, 2.5 \mathrm{mM} \mathrm{CaCl}_{2}\right)$. A fraction $\left(100 \mu \mathrm{L} / 1 \times 10^{5}\right.$ cells $)$ of the cell suspension was incubated with $5 \mu \mathrm{L}$ annexin $\mathrm{V}$ conjugated to FITC and $5 \mu \mathrm{L}$ propidium iodide (PI) for $15 \mathrm{~min}$ at $25^{\circ} \mathrm{C}$ in the dark. $400 \mu \mathrm{L}$ of binding buffer was added to the suspension, and apoptosis was measured immediately using a Becton Dickinson FACScan analyzer. The apoptotic cells were estimated by the percentage of cells that were stained positive for annexin V-FITC while remaining impermeable to PI (AV+/PI-). This method was also able to distinguish viable cells (AV-/PI-) and cells undergoing necrosis $(\mathrm{AV}+/ \mathrm{PI}+)$.

2.5.3. Assay of Caspase Activities. Caspase- 3 and caspase- 9 activities were measured in the cell lysate using detection kits as per the vendor's protocol. The assay is based on spectrophotometric detection of the chromophore $\mathrm{p}$-nitroanilide (pNA) after cleavage from the labeled substrates, DEVDpNA, and LEHD-pNA to measure the activities of caspase3 and caspase-9, respectively. The pNA light emission was then quantified using a microtiter plate reader at $405 \mathrm{~nm}$.

2.6. SDS-PAGE and Western Blot Analysis. Proteins from cell extracts $(30 \mu \mathrm{g})$ from control and STZ-treated cells were separated electrophoretically on 12\% SDS-PAGE [24] and transferred on to nitrocellulose paper by Western blotting [25]. Transferred proteins were probed with primary antibodies against caspase-3, PARP, Akt, p-Akt, NOS-2, Nrf2, Bax, $\mathrm{Bcl}-2$, and GLUT 2. Immunoreactive bands were visualized using the appropriate conjugated secondary antibodies. Equal loading of protein was confirmed using beta-actin as the loading control. After the development of the blots, the bands were visualized and further densitometric analysis was performed using the Typhoon FLA 9500 system (GE Healthcare, Uppsala, Sweden) and expressed as relative ratios normalized against actin or other proteins as appropriate.

2.7. Measurement of CYP 450-Dependent Enzyme Activities. CYP1A1 and CYP1A2 activities in the microsomal fraction from treated and untreated control cells were measured spectrofluorometrically using 7-ethoxyresorufin and methoxyresorufin, respectively, as substrates $[26,27]$ by standard methods as described before [28-30].

2.8. Measurement of GSH Metabolism. Rin-5Fcells were treated with different doses of STZ for different time intervals as mentioned above. GSH/GGSG ratios and activities of GSH-Px and glutathione S-transferase (GST) were measured in the STZ-treated and STZ-untreated control cell extracts. GSH/GGSG ratios were measured using the GSH/GGSGGlo kit as per the vendor's protocol. Briefly, STZ-treated and STZ-untreated control cells were lysed with either total or oxidized glutathione reagent. For the oxidized glutathione measurement, the total GSH was blocked using NEM reagent and the oxidized glutathione was reduced. The total reduced glutathione then converts a specific probe, luciferin-NT to luciferin in the presence of a GST enzyme coupled to firefly luciferase. The luciferin formed gives a luminescent signal, which is proportional to the amount of GSH. The total glutathione and oxidized glutathione are then measured from the standard curve, and the GSH/GSSG ratios calculated. GST activity using CDNB [31] and GSH-Px activity using cumene hydroperoxide [32] as substrates were measured by standard protocols as described before [33-36].

2.9. Measurement of Activities of Mitochondrial Respiratory Enzyme Complexes and ATP Content. Cell extracts ( $5 \mu \mathrm{g}$ protein) from STZ-treated and STZ-untreated control Rin-5F cells were suspended in $1.0 \mathrm{~mL}$ of $20 \mathrm{mM} \mathrm{KPi}$ buffer, $\mathrm{pH} 7.4$, in the presence of the detergent, lauryl maltoside (0.2\%). NADH ubiquinone oxidoreductase (complex I), succinate-cytochrome $\mathrm{c}$ reductase (complex II/III), and cytochrome c oxidase (complex IV) were measured using the substrates coenzyme Q2, succinate-cytochrome $c$, and reduced cytochrome c, respectively, by the methods of Birch-Machin and Turnbull [37] as described before [35, 36]. The ATP content in control and STZ-treated cells was determined using the ATP bioluminescent cell assay kit according to the manufacturer's suggestion (Sigma-Aldrich, St Louis, MO), and samples were read using the TD-20/20 luminometer (Turner Designs, Sunnyvale, CA).

2.10. Statistical Analysis. Values shown are expressed as mean \pm SEM of three individual experiments. Statistical significance of the data was assessed using SPSS software (version 23) by analysis of variance followed by Dunnett's post hoc analysis. $P$ values $\leq 0.05$ were considered statistically significant.

\section{Results}

3.1. Effect of STZ on Rin-5F Cell Morphology and Viability. A decrease in mitochondrial dehydrogenase-based cell survival was observed only with higher concentrations of STZ after 2$12 \mathrm{~h}$ (Figure $1(\mathrm{a})$ ). Significant alterations in cell viability were observed even at low concentration after 24-48 h treatments. The maximum inhibition (60-70\%) was observed in cells treated with $10 \mathrm{mM} \mathrm{STZ}$ for $24 \mathrm{~h}$ and $48 \mathrm{~h}$. Since significant alterations in cell viability were observed at $24 \mathrm{~h}$ and $48 \mathrm{~h}$, with minimal toxicity using $1 \mathrm{mM} \mathrm{STZ}$ and maximal toxicity using $10 \mathrm{mM}$ STZ, these two time points and concentrations were used in our further studies to elucidate the mechanism of STZ toxicity.

Figure 1(b) shows the morphology of control untreated Rin-5F cells as well as cells treated with different doses of STZ at different time intervals. As seen in the figure, after STZ treatment, the normal flattened cells tend to round off, losing their normal morphology. When the cells were treated with $10 \mathrm{mM}$ STZ for $48 \mathrm{~h}$, the rounded cells started detaching from the plate, indicating increased cell death.

3.2. Effect of STZ on Oxidative Stress. Increased ROS production in Rin-5F cells treated with different doses of STZ at different time intervals was captured microscopically using the probe, DCFDA, which measures the overall ROS production. Maximum fluorescence was observed with $10 \mathrm{mM} \mathrm{STZ}$ at $24 \mathrm{~h}$ and $48 \mathrm{~h}$ (Figure 2(a)). A time- and dose-dependent 


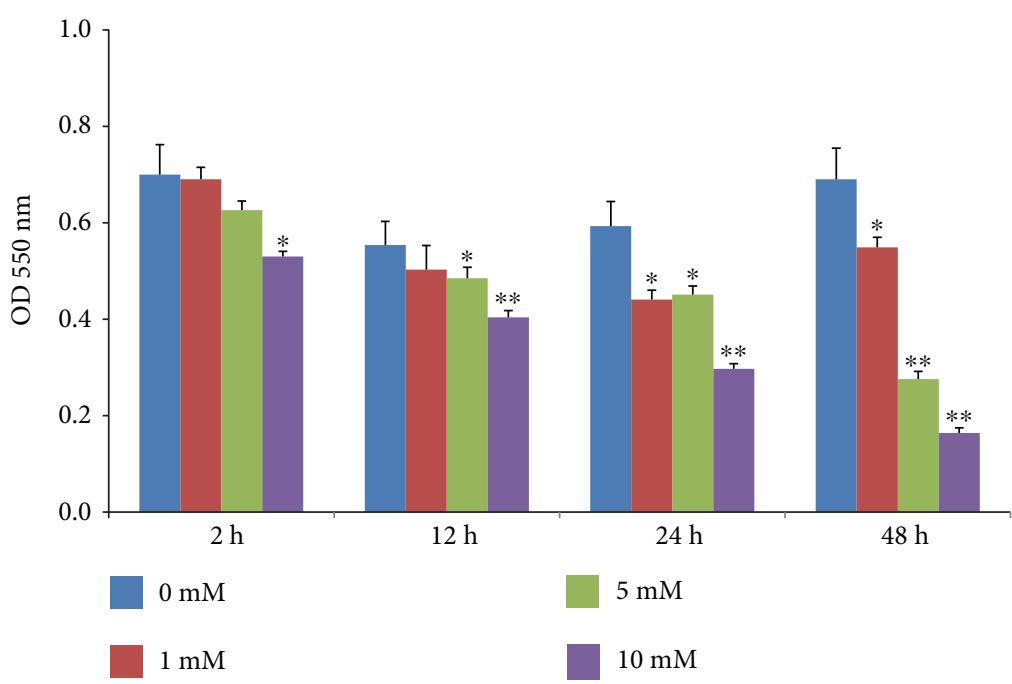

(a)
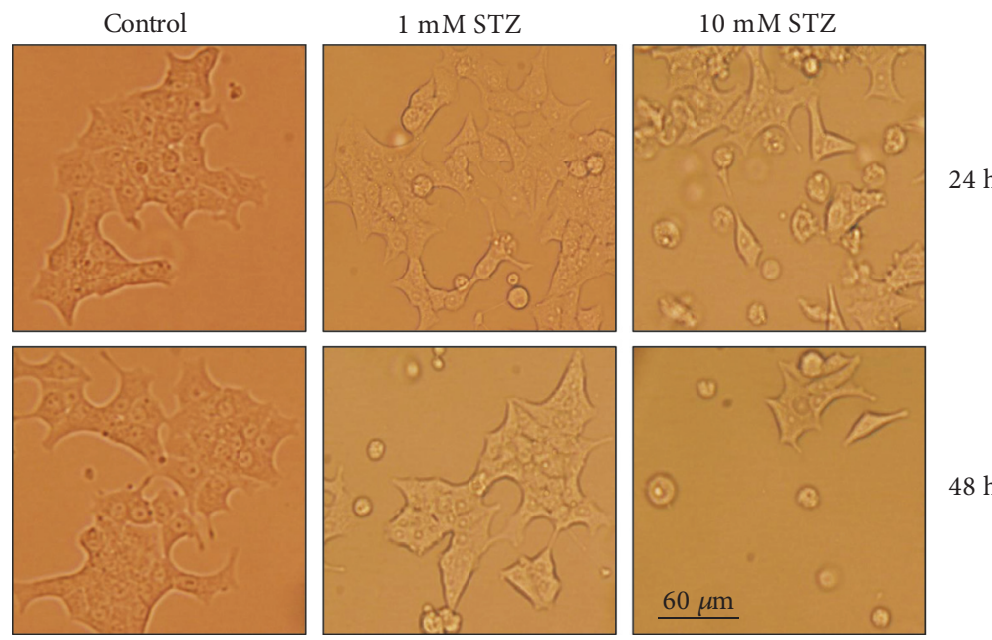

(b)

FIGURE 1: MTT cell viability assay and morphology of cells after STZ treatment. Rin-5F cells $\left(\sim 2 \times 10^{4}\right)$ were grown in 96 -well plates for $24 \mathrm{~h}$ and treated with different concentrations $(0-10 \mathrm{mM})$ of STZ for different time intervals. The formazan crystals formed, following the reduction of MTT by metabolically active (viable) cells, were solubilized in acidified isopropanol and quantitated using the ELISA reader at $550 \mathrm{~nm}$ (a). Results are expressed as mean \pm SEM for three experiments. Asterisks indicate significant difference $\left({ }^{*} p \leq 0.05,{ }^{* *} p \leq 0.005\right)$ relative to the untreated control cells. The morphological integrity of the STZ-treated and STZ-untreated control cells was also checked and photographed (20x) under a light microscope (b).

increase in intracellular ROS production was also measured fluorometrically as shown in Figure 2(b). Significant increases in ROS production were observed, with a marked increase (2-fold and 3-fold) observed with $10 \mathrm{mM} \mathrm{STZ}$ at $24 \mathrm{~h}$ and $48 \mathrm{~h}$, respectively.

NO production was significantly increased $(25-40 \%)$ in Rin-5F cells treated with $10 \mathrm{mM}$ STZ for 24 or $48 \mathrm{~h}$ (Figure 3(a)) whereas a marginal increase was observed with $1 \mathrm{mM}$ STZ treatment after $48 \mathrm{~h}$.

In parallel to ROS production, LPO was significantly increased in a dose- and time-dependent manner after treatment with STZ (Figure 3(b)). Treatment with $10 \mathrm{mM}$ STZ for $48 \mathrm{~h}$ had markedly increased the production of malondialdehyde (MDA). These results clearly indicate the increased oxidative stress in Rin-5Fcells treated with STZ.
3.3. Effects of STZ on Cell Survival and Apoptosis. STZ induced time- and dose-dependent apoptosis in Rin-5F cells as detected by an increase in nuclear condensation was observed by Hoechst staining (Figure 4).

Figure 5(a) shows a significant increase in the percentage of cells undergoing early/late apoptosis by increasing the time and dose of STZ treatment. Treatment of Rin-5F cells with $1 \mathrm{mM} \mathrm{STZ}$ for $24 \mathrm{~h}$ caused $12 \%$ of cells to go into late apoptosis, which further increased to $22 \%$ at $10 \mathrm{mM} \mathrm{STZ \text {. }}$ Moreover, increasing the time of STZ treatment caused a further increase in the late apoptotic cells (almost 20\% to $36 \%$ at $1 \mathrm{mM}$ and $10 \mathrm{mM}$, respectively). The histogram in Figure 5(a) represents the percentage of total apoptotic cells after treatment with STZ at different concentrations and time intervals. This increase in apoptosis was also confirmed by 

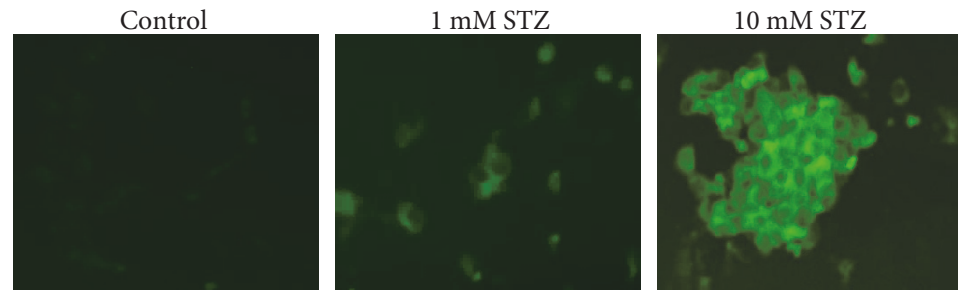

$24 \mathrm{~h}$
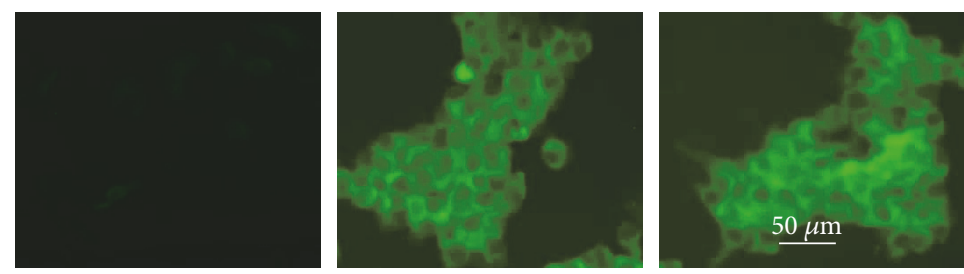

(a)

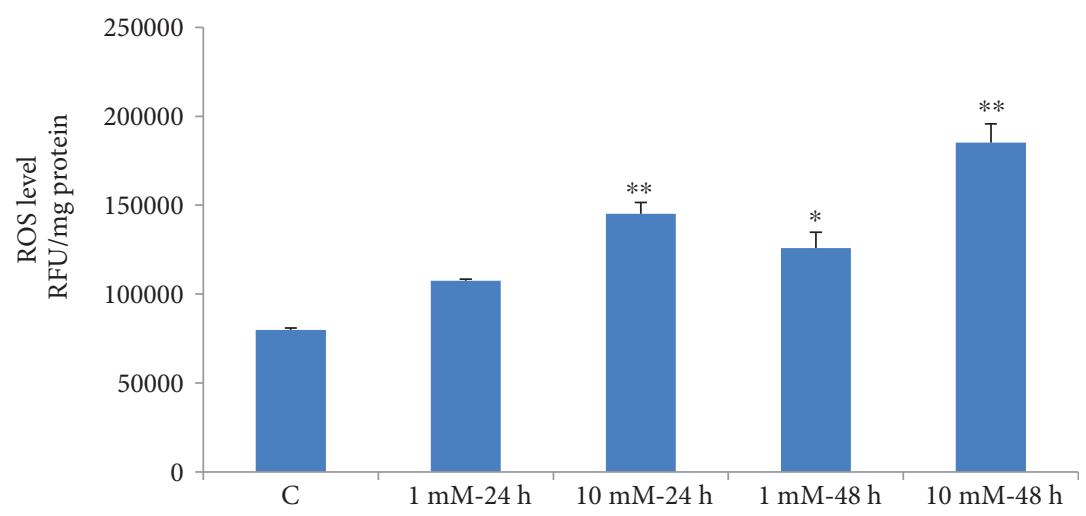

(b)

FIGURE 2: ROS production in STZ-induced cells. Intracellular production of reactive oxygen species was measured in control untreated and STZ-treated Rin-5F cells with different concentrations $(0-10 \mathrm{mM})$ for different time intervals, using the cell permeable probe, DCFDA. Cells $\left(\sim 1 \times 10^{5}\right.$ cells $\left./ \mathrm{mL}\right)$ were grown on cover slips and incubated with $5 \mu \mathrm{M}$ DCFDA for $30 \mathrm{~min}$ at $37^{\circ} \mathrm{C}$. Cells were washed twice with PBS, and fluorescence was immediately visualized using an Olympus fluorescence microscope. Representative slides from untreated control and STZtreated cells from three experiments are shown (a). Original magnification $\times 200$. Production of reactive oxygen species was also measured fluorimetrically in control untreated and STZ-treated cells (b). Results are expressed as mean \pm SEM of three experiments. Asterisks indicate significant difference $\left({ }^{*} p \leq 0.05,{ }^{* *} p \leq 0.005\right)$ relative to the untreated control cells.

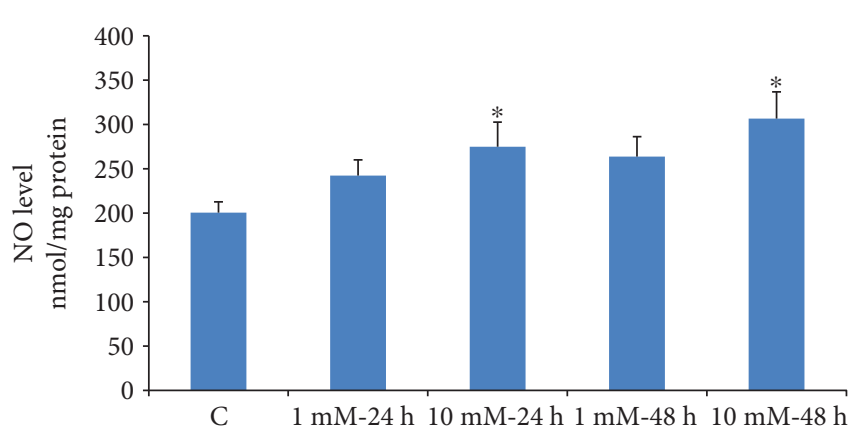

(a)

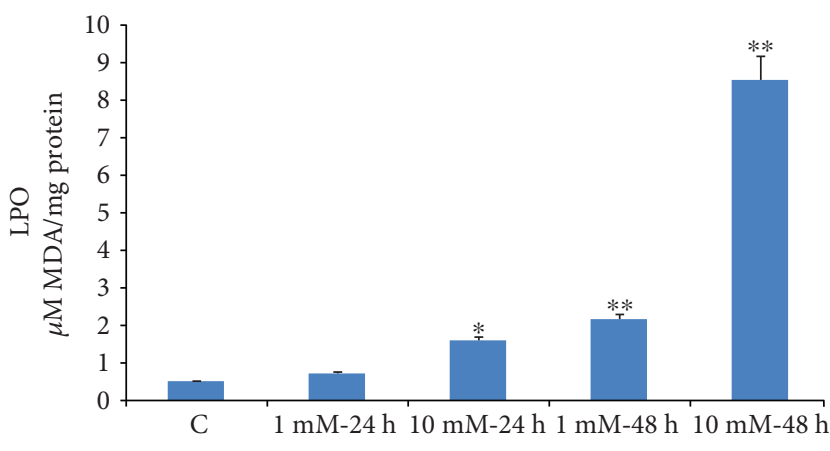

(b)

FIGURE 3: NO production and lipid peroxidation in STZ-induced cells. NO production was determined by measuring the concentration of total nitrite in the culture supernatants (a) with Griess reagent (R\&D Systems Inc.). Lipid peroxidation (LPO) in the control and STZtreated cells was measured as total amount of malondialdehyde (b) as per the vendor's protocol (Oxis Research Inc.). Results are expressed as mean \pm SEM of three experiments. Asterisks indicate significant difference $\left({ }^{*} p \leq 0.05,{ }^{* *} p \leq 0.005\right)$ relative to the untreated control cells. 

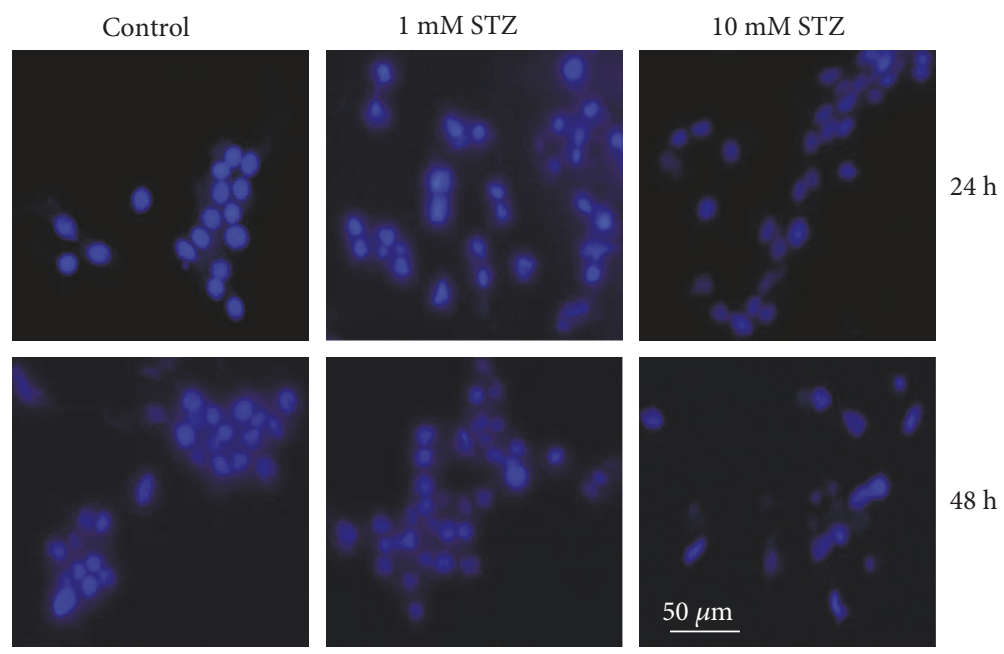

FIGURE 4: STZ-induced DNA fragmentation. Staining of fragmented nuclei of STZ-treated and STZ-untreated cells was performed by using Hoechst33342 dye. Cover slips with adherent cells were treated with STZ, fixed with $3.7 \%$ formaldehyde, and stained with Hoechst33342 $(10 \mu \mathrm{g} / \mathrm{mL})$ for $20 \mathrm{~min}$ at room temperature. The cover slips were washed, mounted on glass slides, and analyzed by fluorescence microscopy. Cells with signs of apoptosis showed fragmented nuclei. Representative slides from three experiments are shown. Original magnification $\times 200$.

increased activities of caspase isoenzymes (3 and 9) (Figure 5(b)). The activity of intrinsic apoptotic enzyme caspase- 9 significantly increased with increasing time and dose of STZ treatment. However, the activities of terminal apoptotic enzyme caspase- 3 showed significant increase after treatment with $10 \mathrm{mM} \mathrm{STZ}$ at $24 \mathrm{~h}$ and $48 \mathrm{~h}$.

\subsection{Effect of STZ on the Expression of Apoptotic Marker} Proteins. Figure 6(a) shows alterations in the expression of oxidative stress marker proteins, NOS-2 and Nrf2. In increased phosphorylation of the cell signaling kinase, Akt was observed at high doses of STZ. A mild increase in GLUT 2 expression was observed suggesting increased STZ/glucose uptake through this mechanism. Figure 6(b) shows a marked cleavage of apoptotic marker protein, caspase-3, as well as PARP and alterations in the expression of intrinsic mitochondrial-specific proteins like Bcl-2 and $\mathrm{Bax}$ which were also observed at high doses. All of these results confirm the increased oxidative stress observed in these cells after STZ treatment.

3.5. Effects of STZ on CYP 450 Activities. Isoenzyme-specific substrates were used to measure the microsomal activities of CYP1A1 and CYP1A2 in Rin-5F cells treated with STZ at different doses and time intervals. CYP1A1 activity showed significant increase with $10 \mathrm{mM}$ STZ at $24 \mathrm{~h}$ and $48 \mathrm{~h}$ (Figure $7(\mathrm{a})$ ) while no significant increase of enzyme activity was observed with $1 \mathrm{mM}$ STZ. CYP1A2 activity, on the other hand, increased significantly (2-3 fold) at all doses and time points (Figure $7(\mathrm{~b})$ ). These results may suggest the involvement of CYP1A family of isoenzymes in STZ metabolism.

3.6. Effects of STZ on the GSH/GSSG Ratio and GSH Metabolism. Dose- and time-dependent decrease (60-70\%) in the ratio of cellularly reduced GSH and oxidized GSSG was observed after STZ treatment (Figure 8(a)). However, a slight recovery in the GSH/GSSG ratio after $48 \mathrm{~h}$ of treatment with lower dose of STZ suggests some delay in recycling of oxidized GSSG.

GSH-conjugating enzyme, GST, was however significantly increased (almost 2 fold) at high doses of STZ (Figure $8(\mathrm{~b})$ ). On the other hand, a marginal increase was observed with $1 \mathrm{mM}$ STZ at $48 \mathrm{~h}$. A marked increase (about 6-8 fold) in GSH-Px activity was also observed when cells were treated with $10 \mathrm{mM}$ STZ both at $24 \mathrm{~h}$ and $48 \mathrm{~h}$ (Figure $8(\mathrm{c})$ ). Though statistically not significant, a marginal increase in enzyme activity was also observed in cells treated with $1 \mathrm{mM} \mathrm{STZ}$ for $24 \mathrm{~h}$. These results may suggest an increased cellular GSH conjugation and detoxification mechanism as an adaptation towards STZ metabolism and toxicity.

3.7. Effects of STZ on Mitochondrial Respiratory Function and ATP Production. Figure 9 shows the effects of STZ treatment on mitochondrial respiratory enzymes and bioenergetics. Both $1 \mathrm{mM}$ and $10 \mathrm{mM}$ STZ caused a significant inhibition (40-50\%) in NADH ubiquinone oxidoreductase (complex I) enzyme activity after $24 \mathrm{~h}$ and $48 \mathrm{~h}$ (Figure 9(a)). The activity of succinate-cytochrome $c$ reductase (complex II/III) was also significantly inhibited (40-65\%) after $24 \mathrm{~h}$ and $48 \mathrm{~h}$, with both $1 \mathrm{mM}$ and $10 \mathrm{mM}$ STZ (Figure 9(b)). On the other hand, the activity of the terminal respiratory enzyme complex IV was markedly inhibited (6-8 fold) by increasing the dose and time of STZ treatment (Figure 9(c)). Consistent to the reduction in mitochondrial respiratory activity, ATP levels were also markedly decreased by increasing the dose and the time of STZ treatment (Figure 9(d)).

3.8. The Mechanism of STZ-Induced Cytotoxicity in Rin-5F Cells. Figure 10 shows a schematic model depicting the mechanisms of STZ-induced cytotoxicity in Rin-5F cells. 

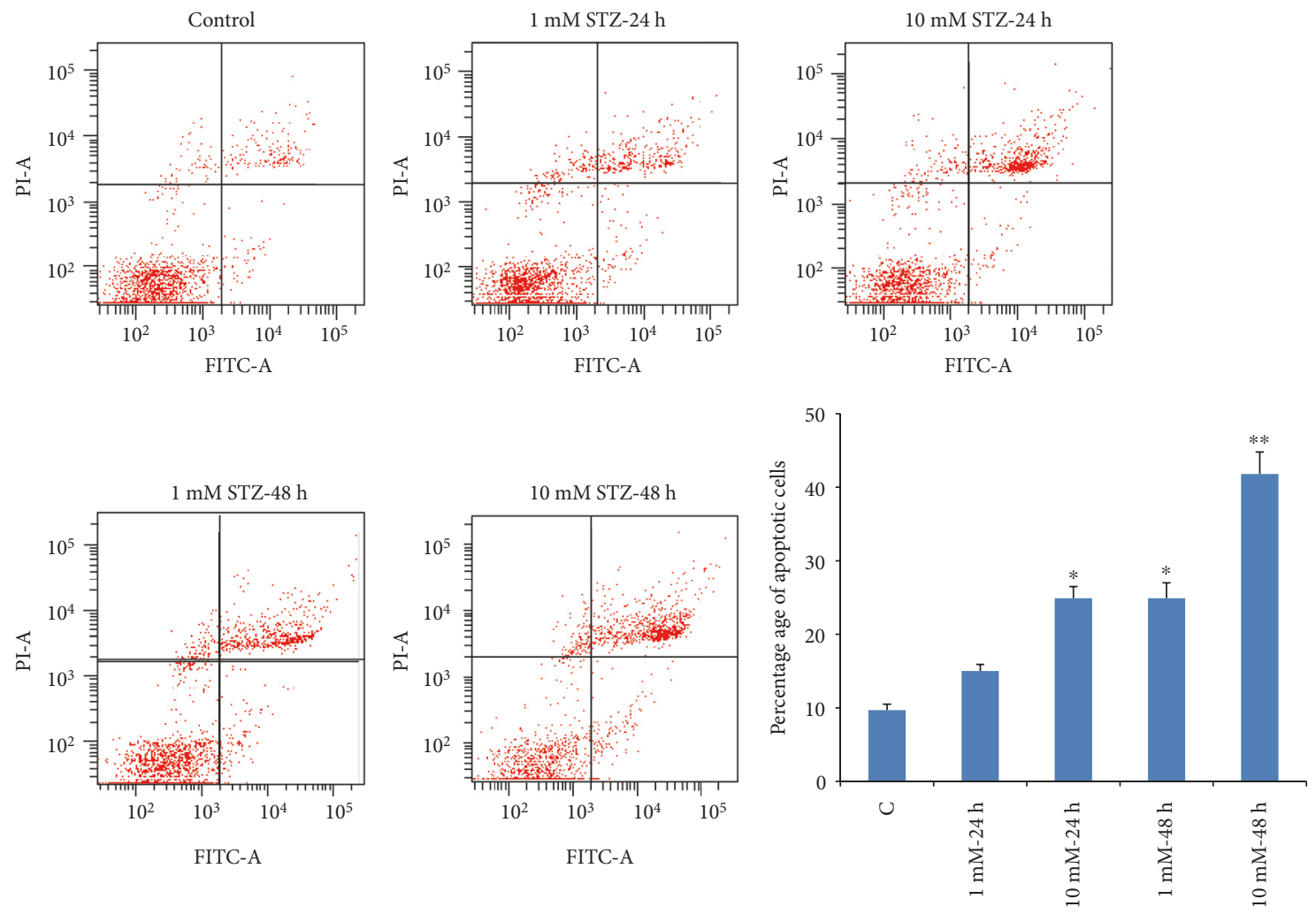

(a)

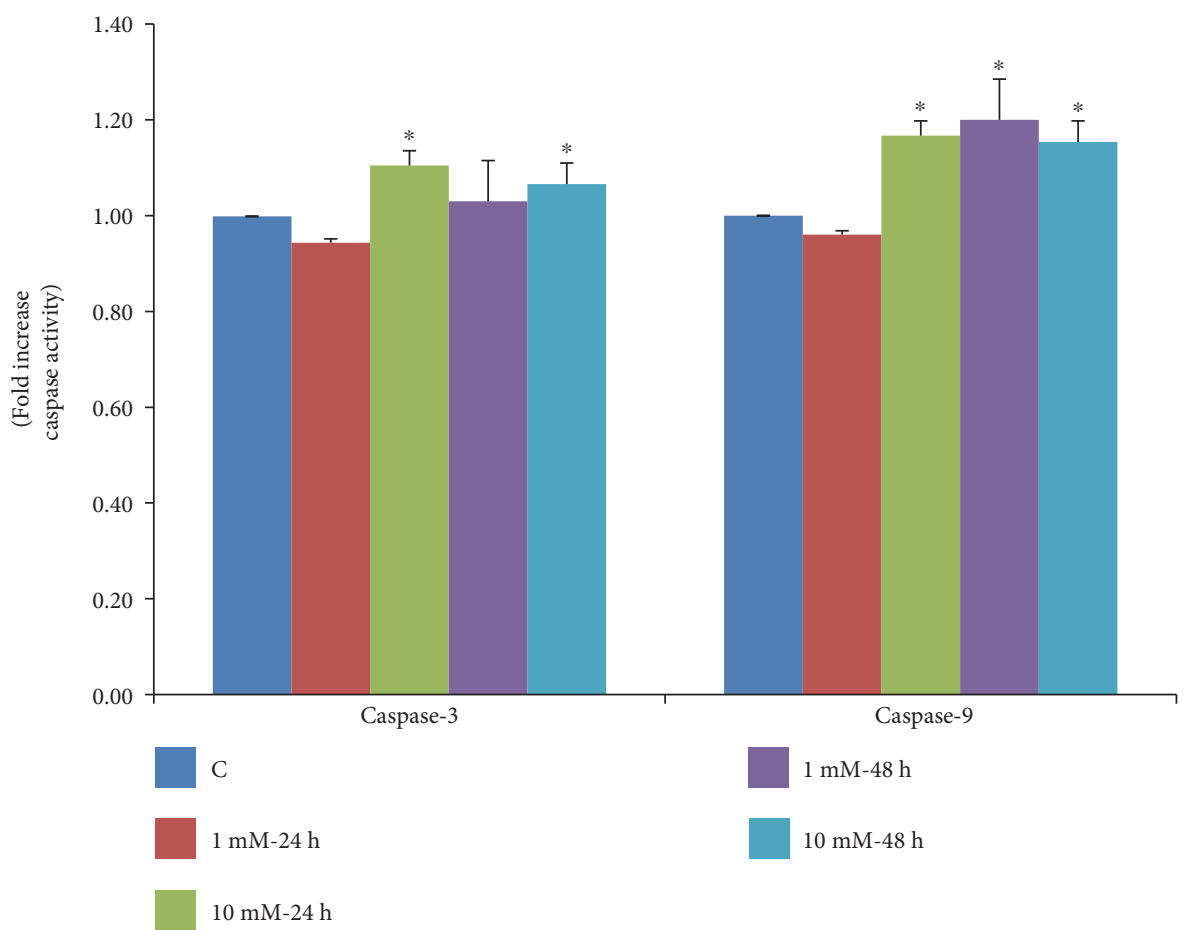

(b)

FIGURE 5: STZ-induced apoptosis. Apoptosis was measured in Rin-5F cells treated with different doses of STZ at different time intervals by flow cytometry using FACSDiva software. Representative dot plots are shown, and percentage of apoptotic cells is represented as a histogram (a). Activity of caspases was measured in cells (b) treated with different doses of STZ at different time intervals colorimetrically using the respective substrates as described in the vendor's protocol (R\&D Systems Inc.). Results are expressed as mean \pm SEM of three experiments. Asterisks indicate significant difference $\left({ }^{*} p \leq 0.05,{ }^{* *} p \leq 0.001\right)$ relative to the untreated control cells. 

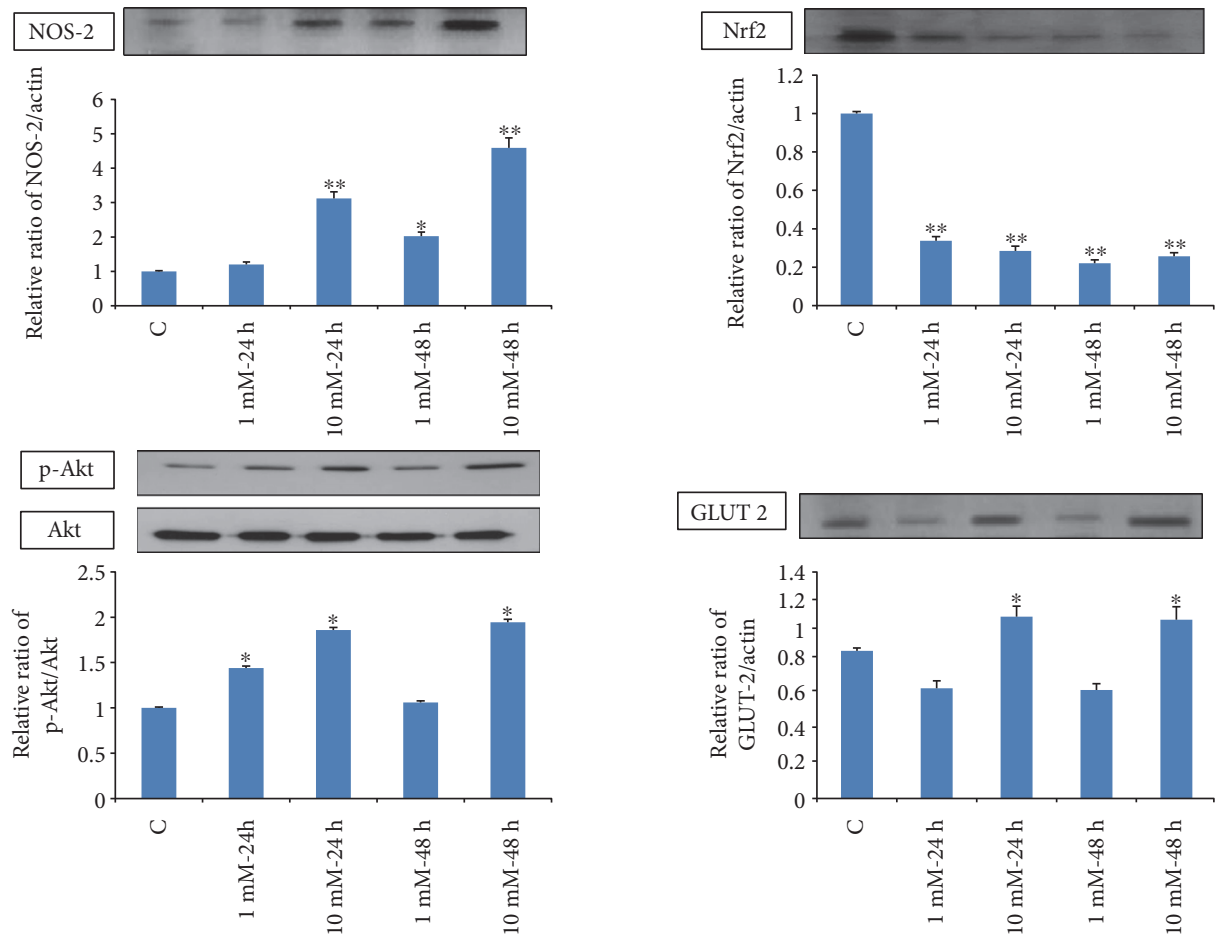

(a)
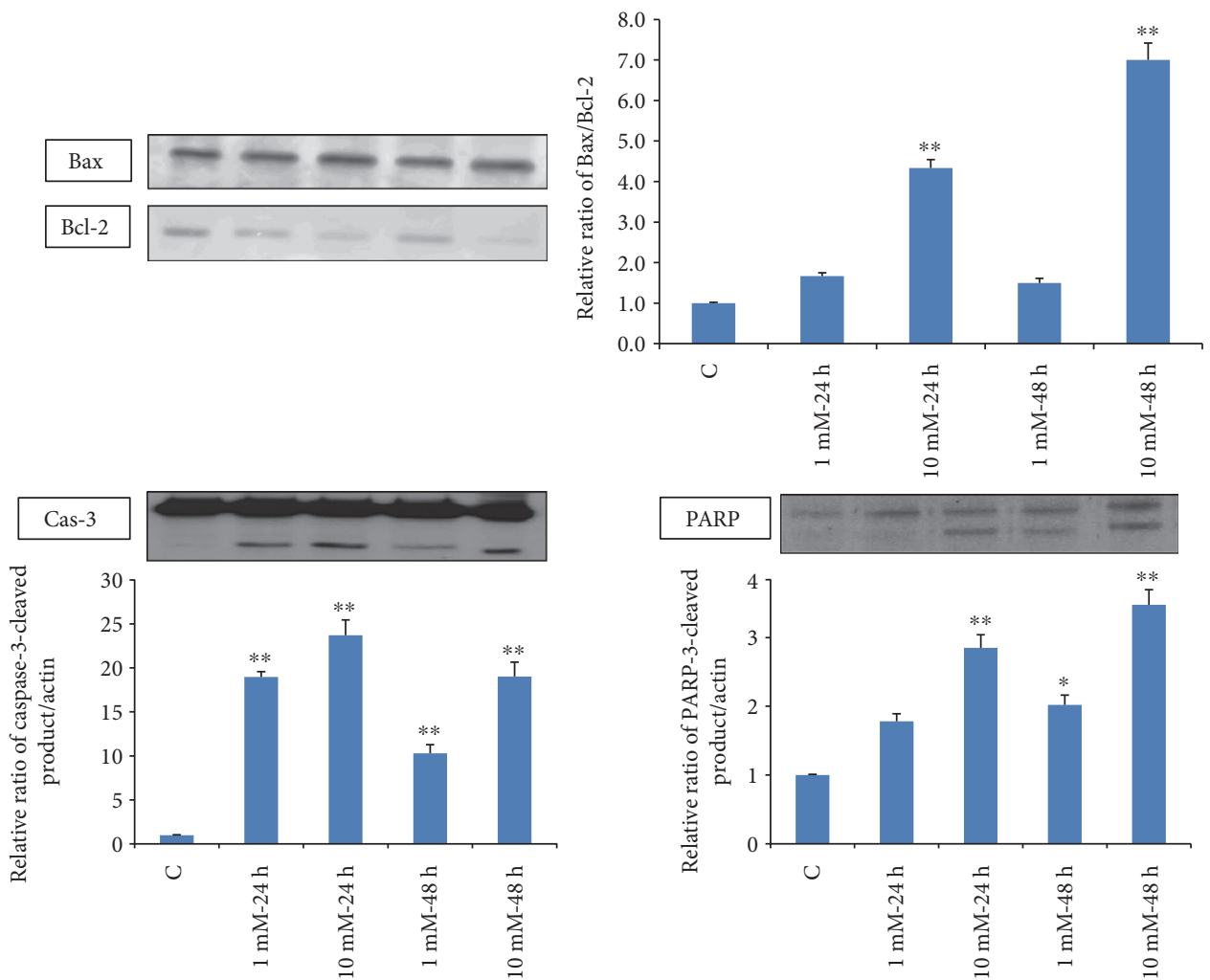

(b)

Figure 6: Expression of apoptotic protein markers. Total extracts ( $30 \mu \mathrm{g}$ protein) from control and Rin-5F cells treated with different doses of STZ at different time intervals were separated on 12\% SDS-PAGE and transferred on to nitrocellulose paper by Western blotting. NOS-2 Nrf2, Akt, p-Akt, and GLUT 2 (a) and caspase-3, PARP, Bax, and Bcl-2 proteins (b) were detected using specific antibodies against these proteins. Beta-actin was used as a loading control. The quantitation of proteins bands is expressed as relative ratios normalized against actin or other proteins as appropriate. The figures are representative of three experiments. Asterisks indicate significant difference $\left({ }^{*} p<0.05,{ }^{* *} p<0.005\right)$ relative to the untreated control cells. 


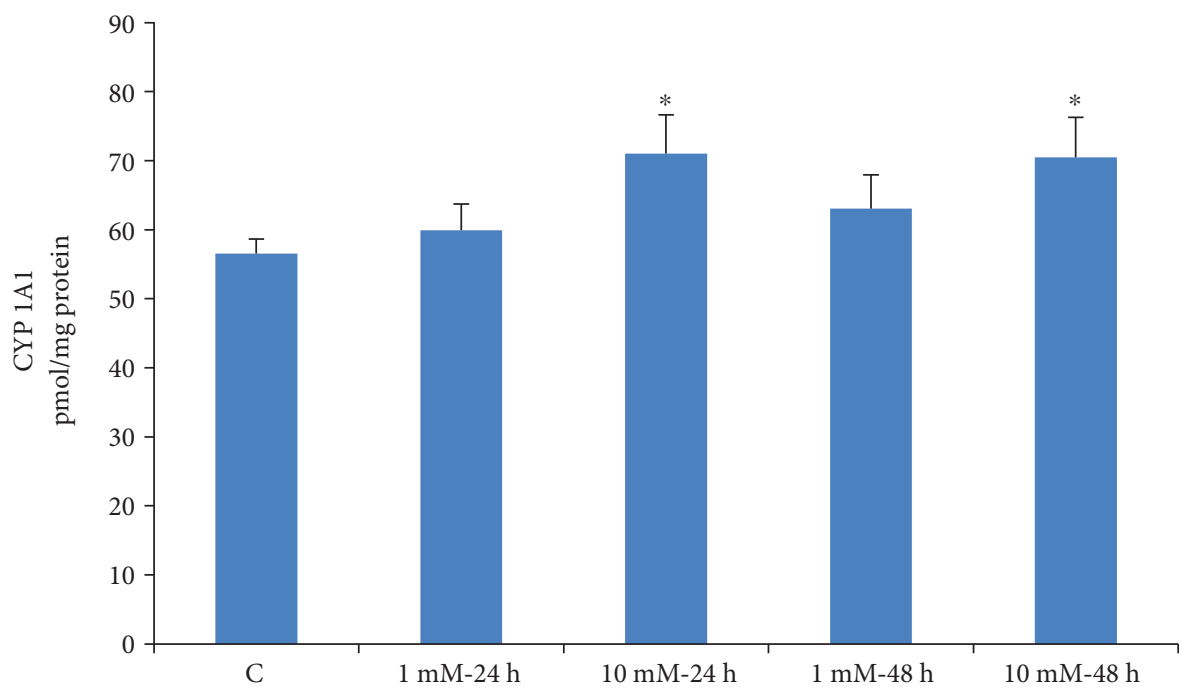

(a)

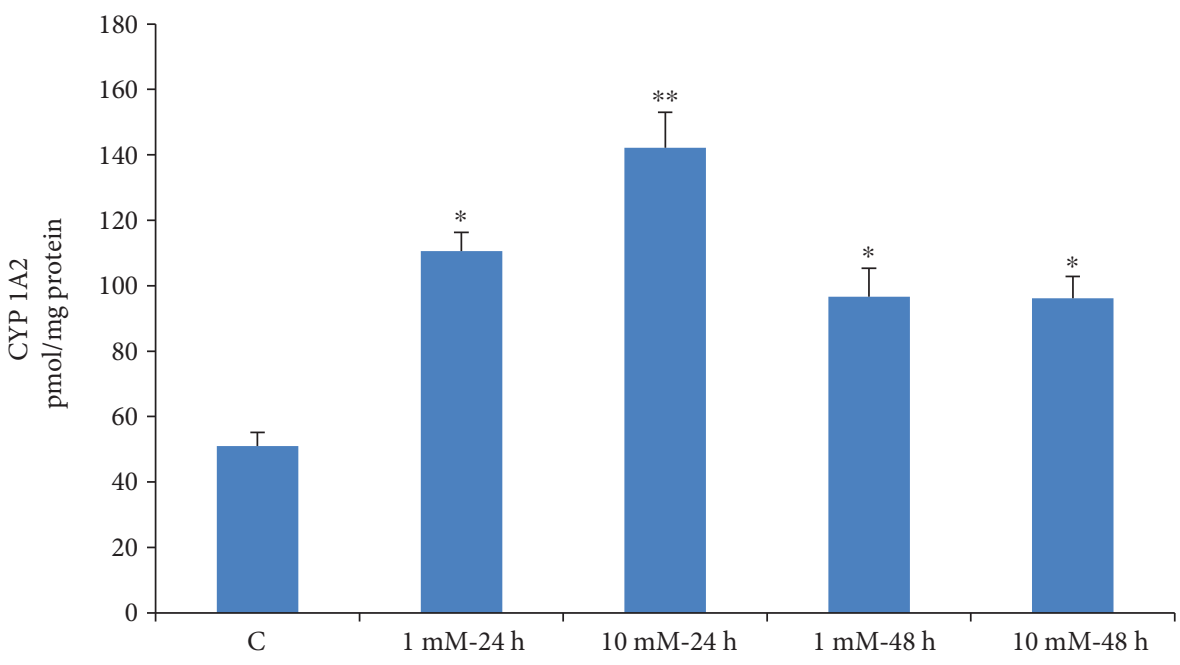

(b)

Figure 7: STZ-induced alterations in CYP activities. CYP 1A1 and CYP 1A2 activities were measured in Rin-5F cells treated with different doses of STZ at different time intervals using the respective substrates as described in the Materials and Methods. Results are expressed as mean \pm SEM of three experiments. Asterisks indicate significant difference $\left({ }^{*} p \leq 0.05,{ }^{* *} p \leq 0.001\right)$ relative to the untreated control cells.

STZ competes with glucose to enter the cells via GLUT 2 receptors, causing Akt phosphorylation, which in turn, causes further translocation of the GLUT 2 receptors. STZinduced cytotoxicity increased ROS/NOS production, LPO, and DNA damage and decreased the GSH/GSSG ratio. Moreover, STZ induced mitochondrial dysfunction through inhibition of the activities of the mitochondrial respiratory enzymes, complex I, complex II/III, and complex IV, and decreased ATP production. STZ treatment induced apoptosis by both caspase-dependent pathway through the activation of caspase- 3 and caspase- 9 and caspase-independent pathway by DNA fragmentation and PARP activation.

\section{Discussion}

Pancreatic $\beta$-cell cytotoxicity has been observed even at therapeutic doses (up to $15 \mathrm{mM}$ ) of STZ when used as an antineoplastic drug for different types of cancer, and this level of STZ induces apoptosis in pancreatic $\beta$-cells $[10,15,38,39]$. Recent studies have shown that STZ is also toxic to neuroendocrine cells of the gut [40] as well as other GLUT 2expressing organs such as the kidneys, liver, and brain [41]. It has been reported that single intracerebroventricular STZ injection chronically decreases glucose uptake and produces effects that resemble features of Alzheimer's disease [41]. Since the cellular uptake of STZ competes with glucose uptake and is considered to be dependent upon the specific expression of selective Glut transporters $[9,42]$, the differential cytotoxicity by STZ in different cellular systems may be associated with the selective uptake of STZ, its metabolic activation, and detoxification in specific cell types as well as on the redox homeostasis and mitochondrial bioenergetics in these cells $[14,43]$. We have previously demonstrated that STZ induces oxidative stress and mitochondrial respiratory 


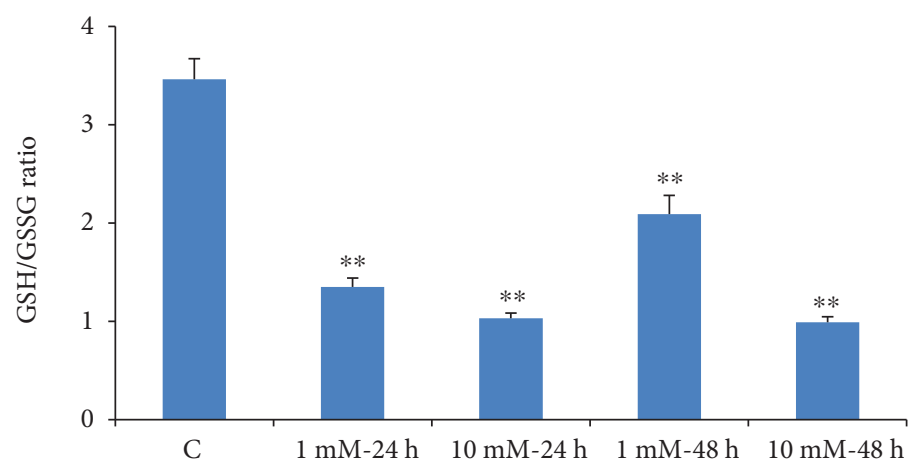

(a)

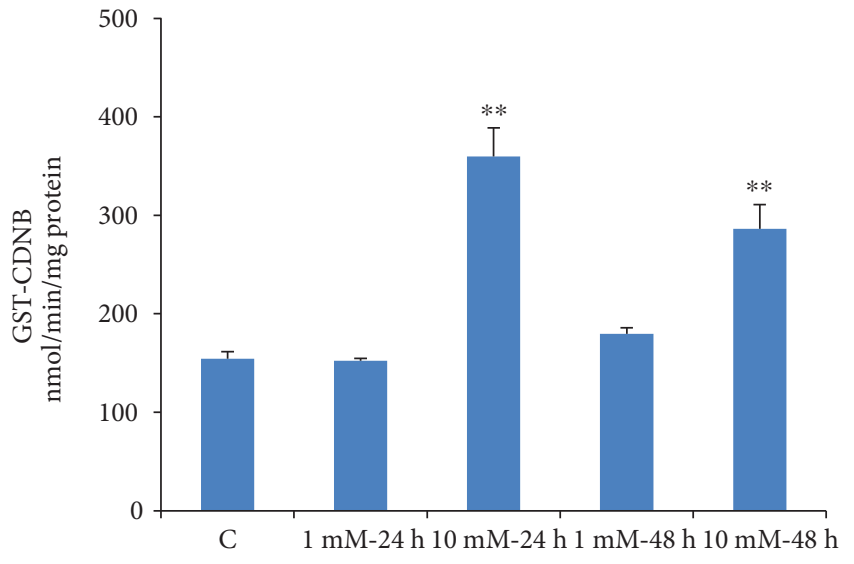

(b)

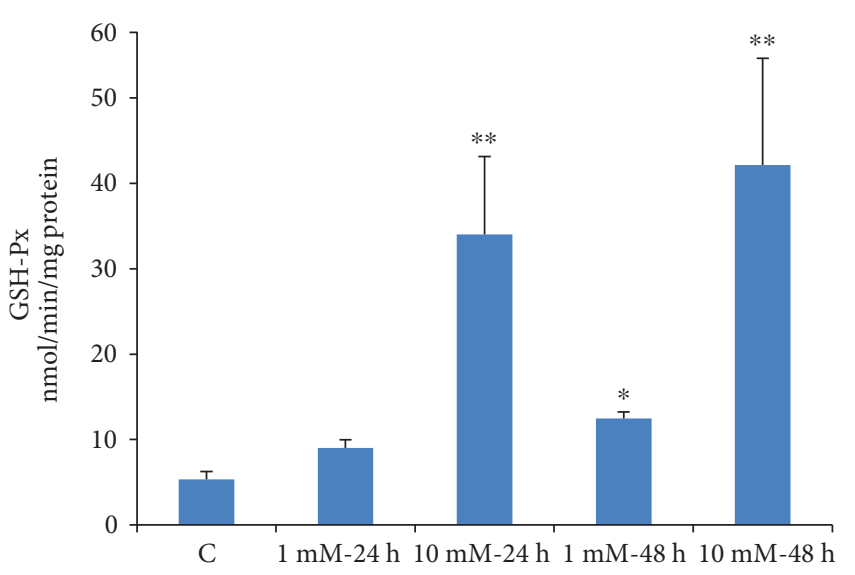

(c)

FIGURE 8: STZ-induced alterations in GSH metabolism. Rin-5F cells were treated with different doses of STZ for different time intervals. GSH/GSSG ratio (a), GST (b), and GSH-Px (c) were measured. Results are expressed as mean \pm SEM of three experiments. Asterisks indicate significant difference $\left({ }^{*} p \leq 0.05,{ }^{* *} p \leq 0.005\right)$ relative to the untreated control cells.

dysfunction not only in the pancreas but also in the liver, kidney, and other organs $[20,44]$. We have also shown that offspring born to STZ-treated diabetic mother rats also exhibited oxidative stress-associated complications in different organs [19]. We have previously reported STZ-induced apoptotic cell death, oxidative stress, and mitochondrial dysfunction in HepG2 cells [18]. Oxidative/nitrosative stress and alterations in mitochondrial function and NF-kB-dependent apoptosis were also reported when HepG2 cells were treated with STZ [18]. Our present study has been further extended to elucidate the mechanism of STZ-induced oxidative stress, alterations in respiratory function, and identification of apoptotic markers in Rin-5F cells treated at different doses and time points. The selection of time points and doses of STZ was based on the alterations in cell viability and morphology (as shown in Figures 1(a) and 1(b)) and also based on our previous studies on HepG2 cells where treatment at lower doses for short time periods had minimum effects on cell viability [18]. Our present results on STZ-treated Rin-5F cells have clearly indicated the increase in ROS/RNS production, increased lipid peroxidation, increased expression of oxidative stress marker protein NOS-2, inhibition in GSH synthesis, and alteration in GSH metabolism by GST and GSHPx. Increased activities of GST and GSH-Px suggest that STZ-induced oxidative stress triggers the activation of antioxidant defensive mechanism to protect the beta-cell death. We also observed marked activation of CYP1A2 activity and moderate activation of CYP1A1 activity in STZtreated Rin-5F cells, probably suggesting the metabolism of STZ by the arylhydrocarbon receptor- (Ahr-) activated CYP1 enzymes. We have previously reported increased expression of CYP isoenzymes in STZ-treated type 1 and type 2 diabetic models $[19,36,45,46]$. However, decreased expression of the antioxidant responsive protein, Nrf2, was observed after STZ treatment, which decreased drastically after $48 \mathrm{~h}$. Pancreatic cells contain very low levels of antioxidant enzymes; thus, these cells are particularly sensitive to oxidative stress [47]. Nrf2 is considered a master regulator of the antioxidant response, and decreased expression of Nrf2 by STZ has been shown by various researchers $[48,49]$. The reason for this loss of Nrf2 expression in pancreatic cells could be due to the STZ-induced increased intracellular ROS and oxidized-to-reduced GSH ratio which has been reported in this study as well as by other researchers. Glutathione transferase (GST) is a detoxifying enzyme that plays a protective role against oxidative stress. The induction of this family of enzymes is thought to be an adaptive response to chemical toxicity and oxidative stress within cells. In addition to Nrf2, GST induction is under the regulation of the "AhR gene battery" as well as other transcription 


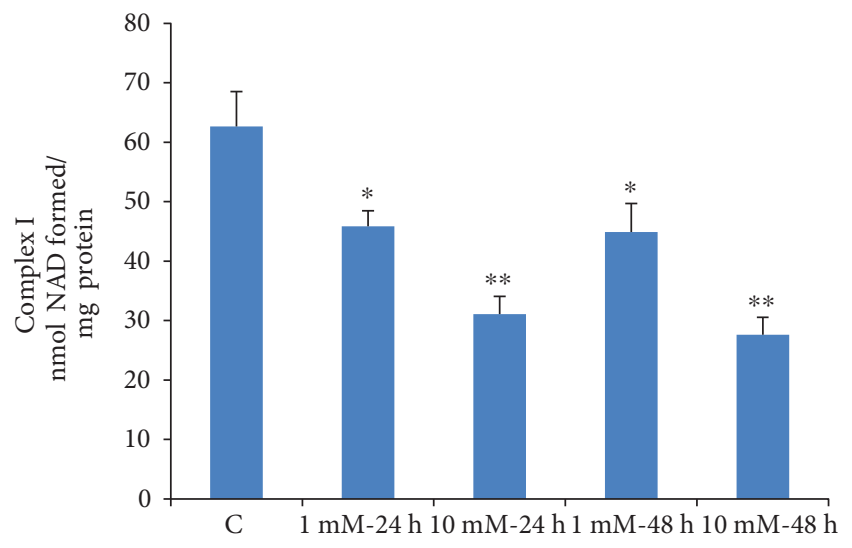

(a)

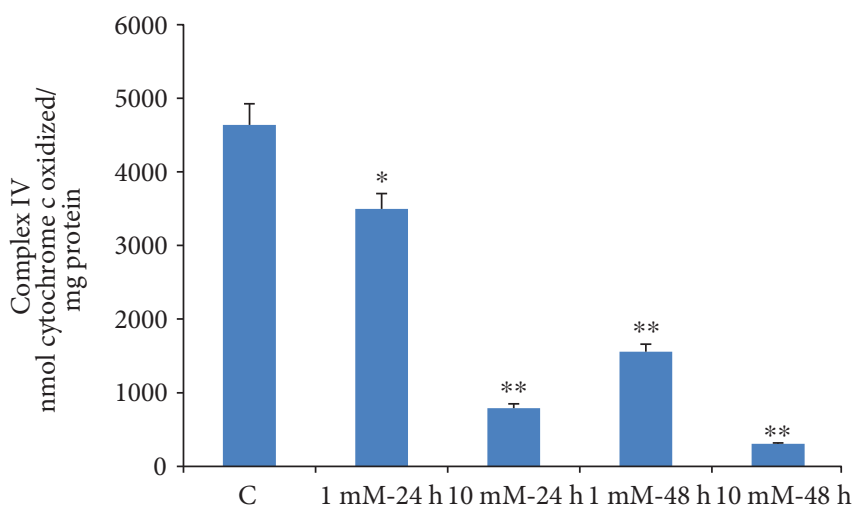

(c)

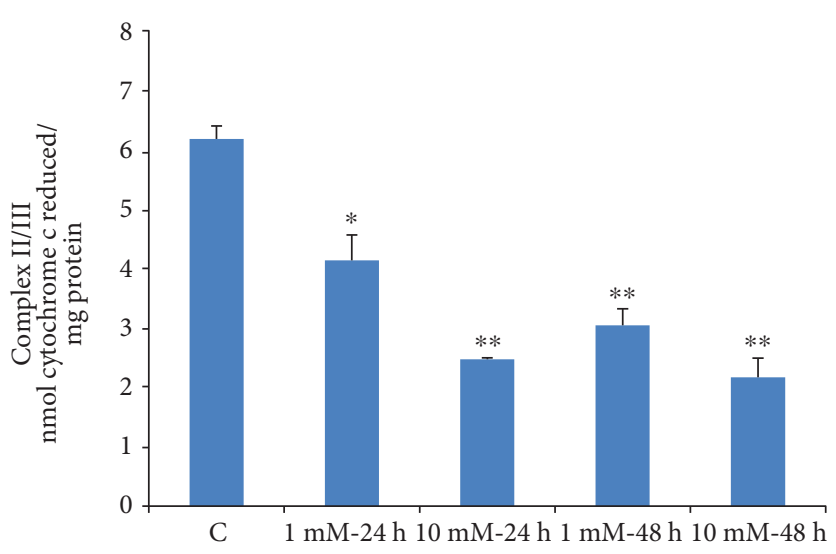

(b)

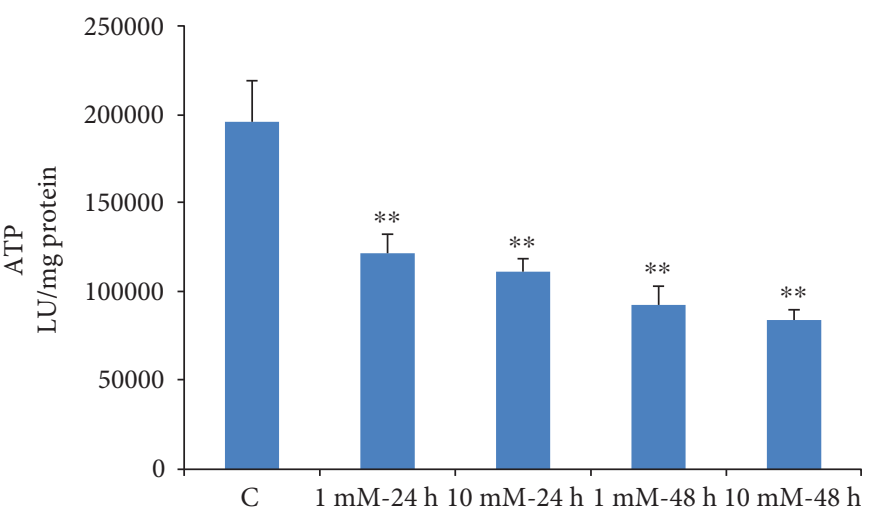

(d)

FIGURE 9: STZ-induced alterations in mitochondrial enzyme activity. Rin-5F cells were treated with different doses of STZ for different time intervals. Respiratory complex I (a) complex II/II (b), and complex IV (c) were measured using their respective substrates as described in the Materials and Methods. ATP content (d) was measured using the ATP bioluminescent somatic cell assay kit. Results are expressed as mean \pm SEM of three experiments. Asterisks indicate significant difference $\left({ }^{*} p \leq 0.05,{ }^{* *} p \leq 0.001\right)$ relative to the untreated control cells.

factors which are activated during chemical detoxification and oxidative stress with increased ROS production. Reports also suggest that the induction of AhR-regulated enzymes, CYP1A1 and 1A2, by xenobiotics also induces various forms of GSTs for their metabolic detoxifications [50-52]. Our present study also demonstrates that the activities of both CYP1A1/1A2 and GST enzymes have been activated after STZ treatment in Rin-5F cells, suggesting the involvement of AhR-dependent activation of CYP1A1/1A2 and GSTs. It has been shown that Nrf2 protein upregulates the antiapoptotic protein, Bcl-2, along with a battery of other cytoprotective proteins and enzymes and prevents cellular apoptosis [53]. In our study, we observed a dose-dependent decrease in Bcl-2 expression with a concomitant increase in proapoptotic protein, Bax, and increased cleavage of caspase- 3 . This could be due to the reduced expression of Nrf2 protein. A dose-dependent increase in PARP cleavage was also observed, which supported our observation on fragmentation of DNA at high doses.

Like HepG2 cells [18], the STZ-treated Rin-5F cells also exhibited mitochondrial dysfunction followed by apoptosis. Activities of mitochondrial respiratory enzymes complex I, complex II/III, and complex IV were significantly inhibited, though the inhibition of complex IV was more pronounced than those of the other complexes, as some recovery in the enzyme activity was seen when cells were treated with $1 \mathrm{mM}$ STZ for $48 \mathrm{~h}$. As expected under these conditions, ATP level was also reduced in STZ-treated cells in a doseand time-dependent manner. Increased oxidative stress and mitochondrial dysfunction resulted in increased apoptosis in STZ-treated Rin-5F cells. More apoptotic cell death was observed with high concentration of STZ $(10 \mathrm{mM})$ for longer duration $(48 \mathrm{~h})$ compared to $1 \mathrm{mM} \mathrm{STZ}$ for $24 \mathrm{~h}$ (Figures 4 and 5). DNA fragmentation and activation of caspase- 3 and caspase-9 confirmed the increased apoptosis after STZ treatment. Thus, the decrease in mitochondrial ATP synthesis and inhibition of respiratory enzymes, increased ROS/RNS production, lipid peroxidation and DNA fragmentation, and increased apoptosis have further confirmed and supported our previous studies as well as numerous other reports on the mechanism of STZ-induced cytotoxicity, in various in vivo and in vitro models, particularly in insulin-secreting pancreatic Rin-5F cells [14, 18, 19, 54-56]. Furthermore, our present study has also identified the increased expression of molecular oxidative stress and apoptotic marker such as NOS-2, as well as cleavage of caspase-3 and PARP in STZtreated Rin-5F cells. In addition, our study also showed that STZ increases the phosphorylation of prosurvival protein, 


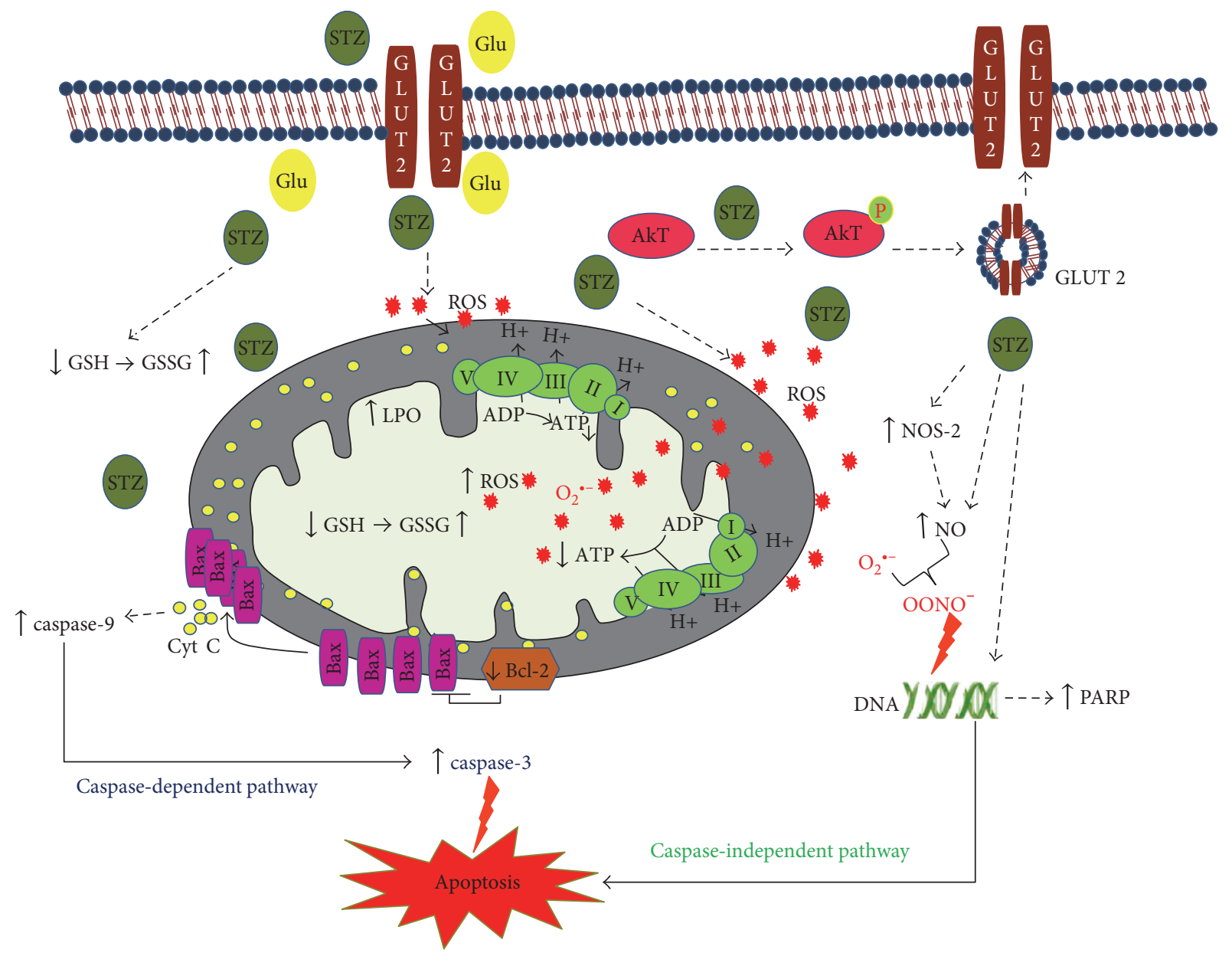

FIGURE 10: Schematic model depicting the mechanism of STZ-induced cytotoxicity in Rin-5F cells. STZ competes with glucose (Glu) to enter the cells via GLUT 2 receptors, causing Akt phosphorylation, which, in turn, causes further translocation of the GLUT 2 receptors. The model also shows that STZ induces cytotoxicity and apoptosis by increased ROS/NOS production, oxidative/nitrosative stress, increased LPO, DNA damage, a decreased GSH/GSSG ratio, and mitochondrial dysfunction. Upward arrows $(\uparrow)$ indicate increase and downward arrows $(\downarrow)$ indicate decrease.

Akt, suggesting a role in altering insulin signaling and GLUT expression. It is possible that STZ stimulates Akt phosphorylation in Rin-5F cells to increase GLUT 2 transport to the membrane for the transport of STZ itself and to protect the cells from further oxidative/metabolic insult. Some studies have reported a corelation between Akt phosphorylation and GLUT 2 expression and translocation. Their reports suggest that expression and membrane translocation of GLUT 2 are substantially reduced in Akt knockout mice [57]. Our study has also confirmed increased GLUT 2 expression with increased Akt phosphorylation at high doses of STZ treatment.

Our results also support the observation reported that STZ induces cell resistance in $\beta$-cells towards its own toxicity. One explanation for this could be that, in addition to the other mechanisms as reported, the STZ-treated cell might be activating the prosurvival signals (e.g., Akt, as observed in this study) and increasing GLUT 2 levels, thus modulating glucose metabolism and uptake. Another reason could be the increased GST/GSH-Px-dependent detoxification processes in $\beta$-cells in order to defend cells from the deleterious effects of STZ and ROS $[58,59]$. The altered expression of redoxsensitive protein, Nrf2, could also be a line of defense to protect the cells from the cytotoxic effects of STZ. A recent study has shown that cellular GST acts as a reservoir for NO and thus scavenges NO and detoxifies ROS [60] via GSH conjugation. This along with the increased GST/GSH-Px-dependent efflux/detoxification of STZ could render increased resistance to the cells against ROS/NO cytotoxicity.

\section{Conclusion}

In summary, here we provide additional evidence and have confirmed that the mechanism of STZ-induced cytotoxicity and apoptosis in Rin-5F cells is mediated by increased oxidative/nitrosative stress, mitochondrial dysfunction, and alterations in cell signaling. In addition, our results also suggest that STZ-treated Rin-5F cells also induces some cellular protection pathways as indicated by altered cell signaling and detoxification mechanisms which might be associated with the development of cellular resistance towards STZ. These results may be 
significant in better understanding the etiological mechanisms involved in STZ-induced toxicity/resistance in pancreatic as well as in other cellular systems.

\section{Abbreviations}

$\begin{array}{ll}\text { STZ: } & \text { Streptozotocin } \\ \text { MTT: } & \text { 3-(4,5-Dimethylthiazol-2-yl)-2,5-diphenyltet- } \\ & \text { razolium bromide } \\ \text { ROS: } & \text { Reactive oxygen species } \\ \text { NO: } & \text { Nitric oxide } \\ \text { LPO: } & \text { Lipid peroxidation } \\ \text { GSH: } & \text { Glutathione } \\ \text { GST: } & \text { Glutathione S-transferase } \\ \text { GSH-Px: } & \text { Glutathione peroxidase } \\ \text { Nrf2: } & \text { Nuclear factor erythroid 2-related factor } 2 \\ \text { CDNB: } & \text { 1-Chloro 2,4-dinitrobenzene } \\ \text { DCFDA: } & 2^{\prime}, 7^{\prime} \text {-Dichlorofluorescein diacetate }\end{array}$

SDS-PAGE: Sodium dodecyl sulfate polyacrylamide gel electrophoresis.

\section{Disclosure}

Part of this research may also be used for the fulfillment of Ph.D. thesis requirement for Ms. Arwa M. T. Al Nahdi.

\section{Conflicts of Interest}

There is no conflict of interest to disclose for any of the authors and funding sources regarding the publication of this manuscript.

\section{Acknowledgments}

The authors wish to thank Sheikh Hamdan Bin Rashed Al Maktoum Award for Medical Research (Haider Raza) for their generous support. Thanks are also due to the support from Research Committee, College of Medicine and Health Sciences, UAE University.

\section{References}

[1] C. Lewis and A. R. Barbiers, "Streptozotocin, a new antibiotic. In vitro and in vivo evaluation," Antibiotics Annual, vol. 7, pp. 247-254, 1959.

[2] R. B. Weiss, "Streptozocin: a review of its pharmacology, efficacy, and toxicity," Cancer Treatment Reports, vol. 66, pp. 427-438, 1982.

[3] M. Eileen Dolan, "Inhibition of DNA repair as a means of increasing the antitumor activity of DNA reactive agents," Advanced Drug Delivery Reviews, vol. 26, pp. 105-118, 1997.

[4] M. S. Capucci, M. E. Hoffmann, and A. T. Natarajan, "Streptozotocin-induced genotoxic effects in Chinese hamster cells: the resistant phenotype of V79 cells," Mutation Research, vol. 347, pp. 79-85, 1995.

[5] M. S. Islam and D. T. Loots, "Experimental rodent models of type 2 diabetes: a review," Methods and Findings in Experimental and Clinical Pharmacology, vol. 31, pp. 249-261, 2009.

[6] L. Wei, Y. Lu, S. He et al., "Induction of diabetes with signs of autoimmunity in primates by the injection of multiple-low- dose streptozotocin," Biochemical and Biophysical Research Communications, vol. 412, pp. 373-378, 2011.

[7] H. Tjälve, E. Wilander, and E. B. Johansson, "Distribution of labelled streptozotocin in mice: uptake and retention in pancreatic islets," The Journal of Endocrinology, vol. 69, pp. 455-456, 1976.

[8] E. H. Karunanayake, J. R. Baker, R. A. Christian, D. J. Hearse, and G. Mellows, "Autoradiographic study of the distribution and cellular uptake of (14C) - streptozotocin in the rat," Diabetologia, vol. 12, pp. 123-128, 1976.

[9] M. Hosokawa, W. Dolci, and B. Thorens, "Differential sensitivity of GLUT1- and GLUT2-expressing beta cells to streptozotocin," Biochemical and Biophysical Research Communications, vol. 289, pp. 1114-1117, 2001.

[10] S. P. LeDoux, S. E. Woodley, N. J. Patton, and G. L. Wilson, "Mechanisms of nitrosourea-induced beta-cell damage. Alterations in DNA," Diabetes, vol. 35, pp. 866-872, 1986.

[11] M. Murata, A. Takahashi, I. Saito, and S. Kawanishi, "Site-specific DNA methylation and apoptosis: induction by diabetogenic streptozotocin," Biochemical Pharmacology, vol. 57, pp. 881-887, 1999.

[12] H. Yamamoto, Y. Uchigata, and H. Okamoto, "Streptozotocin and alloxan induce DNA strand breaks and poly(ADP-ribose) synthetase in pancreatic islets," Nature, vol. 294, pp. 284-286, 1981.

[13] S. Sandler and I. Swenne, "Streptozotocin, but not alloxan, induces DNA repair synthesis in mouse pancreatic islets in vitro," Diabetologia, vol. 25, pp. 444-447, 1983.

[14] M. Nukatsuka, Y. Yoshimura, M. Nishida, and J. Kawada, "Importance of the concentration of ATP in rat pancreatic beta cells in the mechanism of streptozotocin-induced cytotoxicity," The Journal of Endocrinology, vol. 127, pp. 161$165,1990$.

[15] T. Szkudelski, "The mechanism of alloxan and streptozotocin action in B cells of the rat pancreas," Physiological Research, vol. 50, pp. 537-546, 2001.

[16] M. Friederich, P. Hansell, and F. Palm, "Diabetes, oxidative stress, nitric oxide and mitochondria function," Current Diabetes Reviews, vol. 5, pp. 120-144, 2009.

[17] K. Van Dyke, E. Ghareeb, M. Van Dyke, A. Sosa, R. D. Hoeldtke, and D. H. Van Thiel, "Luminescence experiments involved in the mechanism of streptozotocin diabetes and cataract formation," Luminescence, vol. 23, pp. 386-391, 2008.

[18] H. Raza and A. John, "Streptozotocin-induced cytotoxicity, oxidative stress and mitochondrial dysfunction in human hepatoma HepG2 cells," International Journal of Molecular Sciences, vol. 13, pp. 5751-5767, 2012.

[19] H. Raza and A. John, "Glutathione metabolism and oxidative stress in neonatal rat tissues from streptozotocin-induced diabetic mothers," Diabetes/Metabolism Research and Reviews, vol. 20, pp. 72-78, 2004.

[20] H. Raza, S. K. Prabu, A. John, and N. G. Avadhani, "Impaired mitochondrial respiratory functions and oxidative stress in streptozotocin-induced diabetic rats," International Journal of Molecular Sciences, vol. 12, pp. 3133-3147, 2011.

[21] S. Bathina, N. Srinivas, and U. N. Das, "BDNF protects pancreatic $\beta$ cells (RIN5F) against cytotoxic action of alloxan, streptozotocin, doxorubicin and benzo(a)pyrene in vitro," Metabolism, vol. 65, pp. 667-684, 2016.

[22] M. M. Bradford, "A rapid and sensitive method for the quantitation of microgram quantities of protein utilizing the 
principle of protein-dye binding," Analytical Biochemistry, vol. 72, pp. 248-254, 1976.

[23] H. Raza and A. John, "Implications of altered glutathione metabolism in aspirin-induced oxidative stress and mitochondrial dysfunction in HepG2 cells," PLoS One, vol. 7, article e36325, 2012.

[24] U. K. Laemmli, "Cleavage of structural proteins during the assembly of the head of bacteriophage T4," Nature, vol. 227, pp. 680-685, 1970.

[25] H. Towbin, T. Staehelin, and J. Gordon, "Electrophoretic transfer of proteins from polyacrylamide gels to nitrocellulose sheets: procedure and some applications. 1979," Biotechnology (Reading, Mass), vol. 24, pp. 145-149, 1992.

[26] R. J. Pohl and J. R. Fouts, "A rapid method for assaying the metabolism of 7-ethoxyresorufin by microsomal subcellular fractions," Analytical Biochemistry, vol. 107, pp. 150-155, 1980.

[27] P. V. Nerurkar, S. S. Park, P. E. Thomas, R. W. Nims, and R. A. Lubet, "Methoxyresorufin and benzyloxyresorufin: substrates preferentially metabolized by cytochromes P4501A2 and 2B, respectively, in the rat and mouse," Biochemical Pharmacology, vol. 46, pp. 933-943, 1993.

[28] H. Raza, A. John, and J. Shafarin, "NAC attenuates LPSinduced toxicity in aspirin-sensitized mouse macrophages via suppression of oxidative stress and mitochondrial dysfunction," PloS One, vol. 9, article e103379, 2014.

[29] H. Raza, A. John, and A. Nemmar, "Short-term effects of nose-only cigarette smoke exposure on glutathione redox homeostasis, cytochrome P450 1A1/2 and respiratory enzyme activities in mice tissues," Cellular Physiology and Biochemistry, vol. 31, pp. 683-692, 2013.

[30] H. Raza, A. John, and F. C. Howarth, "Increased metabolic stress in Zucker diabetic fatty rat kidney and pancreas," Cellular Physiology and Biochemistry, vol. 32, pp. 1610$1620,2013$.

[31] W. H. Habig, M. J. Pabst, and W. B. Jakoby, "Glutathione S-transferases. The first enzymatic step in mercapturic acid formation," The Journal of Biological Chemistry, vol. 249, pp. 7130-7139, 1974.

[32] D. E. Paglia and W. N. Valentine, "Studies on the quantitative and qualitative characterization of erythrocyte glutathione peroxidase," The Journal of Laboratory and Clinical Medicine, vol. 70, pp. 158-169, 1967.

[33] H. Raza and A. John, "4-hydroxynonenal induces mitochondrial oxidative stress, apoptosis and expression of glutathione S-transferase A4-4 and cytochrome P450 2E1 in PC12 cells," Toxicology and Applied Pharmacology, vol. 216, pp. 309-318, 2006.

[34] H. Raza, M.-A. Robin, J. K. Fang, and N. G. Avadhani, "Multiple isoforms of mitochondrial glutathione S-transferases and their differential induction under oxidative stress," The Biochemical Journal, vol. 366, pp. 45-55, 2002.

[35] H. Raza, A. John, and J. Shafarin, "Potentiation of LPSinduced apoptotic cell death in human hepatoma HepG2 cells by aspirin via ROS and mitochondrial dysfunction: protection by N-acetyl cysteine," PLoS One, vol. 11, article e0159750, 2016.

[36] H. Raza, A. John, and F. C. Howarth, "Increased oxidative stress and mitochondrial dysfunction in zucker diabetic rat liver and brain," Cellular Physiology and Biochemistry, vol. 35, pp. 1241-1251, 2015.
[37] M. A. Birch-Machin and D. M. Turnbull, "Assaying mitochondrial respiratory complex activity in mitochondria isolated from human cells and tissues," Methods in Cell Biology, vol. 65, pp. 97-117, 2001.

[38] J. Wu and L.-J. Yan, "Streptozotocin-induced type 1 diabetes in rodents as a model for studying mitochondrial mechanisms of diabetic $\beta$ cell glucotoxicity," Diabetes, Metabolic Syndrome and Obesity: Targets and Therapy, vol. 8, pp. 181-188, 2015.

[39] K. S. Saini, C. Thompson, C. M. Winterford, N. I. Walker, and D. P. Cameron, "Streptozotocin at low doses induces apoptosis and at high doses causes necrosis in a murine pancreatic beta cell line, INS-1," Biochemistry and Molecular Biology International, vol. 39, pp. 1229-1236, 1996.

[40] O. Brenna, G. Qvigstad, E. Brenna, and H. L. Waldum, "Cytotoxicity of streptozotocin on neuroendocrine cells of the pancreas and the gut," Digestive Diseases and Sciences, vol. 48, pp. 906-910, 2003.

[41] P. Grieb, "Intracerebroventricular Streptozotocin injections as a model of Alzheimer's disease: in search of a relevant mechanism," Molecular Neurobiology, vol. 53, pp. 17411752, 2016.

[42] W. J. Schnedl, S. Ferber, J. H. Johnson, and C. B. Newgard, "STZ transport and cytotoxicity. Specific enhancement in GLUT2-expressing cells," Diabetes, vol. 43, pp. 1326-1333, 1994.

[43] S. Zheng, M. Zhao, Y. Ren, Y. Wu, and J. Yang, "Sesamin suppresses STZ induced INS-1 cell apoptosis through inhibition of NF- $\kappa$ B activation and regulation of Bcl-2 family protein expression," European Journal of Pharmacology, vol. 750, pp. 52-58, 2015.

[44] H. Raza, I. Ahmed, and A. John, "Tissue specific expression and immunohistochemical localization of glutathione Stransferase in streptozotocin induced diabetic rats: modulation by Momordica charantia (karela) extract," Life Sciences, vol. 74, pp. 1503-1511, 2004.

[45] H. Raza, A. John, J. Shafarin, and F. C. Howarth, "Exerciseinduced alterations in pancreatic oxidative stress and mitochondrial function in type 2 diabetic Goto-Kakizaki rats," Physiological Reports, vol. 4, 2016.

[46] H. Raza, I. Ahmed, A. John, and A. K. Sharma, "Modulation of xenobiotic metabolism and oxidative stress in chronic streptozotocin-induced diabetic rats fed with Momordica charantia fruit extract," Journal of Biochemical and Molecular Toxicology, vol. 14, pp. 131-139, 2000.

[47] Y. Y. Jang, J. H. Song, Y. K. Shin, E. S. Han, and C. S. Lee, "Protective effect of boldine on oxidative mitochondrial damage in streptozotocin-induced diabetic rats," Pharmacological Research, vol. 42, pp. 361-371, 2000.

[48] B. Elango, S. Dornadula, R. Paulmurugan, and K. M. Ramkumar, "Pterostilbene ameliorates Streptozotocininduced diabetes through enhancing antioxidant signaling pathways mediated by Nrf2," Chemical Research in Toxicology, vol. 29 , pp. 47-57, 2016.

[49] K. A. Kang, J. S. Kim, R. Zhang et al., "KIOM-4 protects against oxidative stress-induced mitochondrial damage in pancreatic $\beta$-cells via its antioxidant effects," Evidence-Based Complementary and Alternative Medicine: ECAM, vol. 2011, Article ID 978682, 11 pages, 2011.

[50] H. M. Korashy and A. O. S. El-Kadi, "The role of aryl hydrocarbon receptor and the reactive oxygen species in the modulation of glutathione transferase by heavy metals in 
murine hepatoma cell lines," Chemico-Biological Interactions, vol. 162, pp. 237-248, 2006.

[51] T. R. Knight, S. Choudhuri, and C. D. Klaassen, "Induction of hepatic glutathione S-transferases in male mice by prototypes of various classes of microsomal enzyme inducers," Toxicological Sciences, vol. 106, pp. 329-338, 2008.

[52] M. Connolly, M. L. Fernández-Cruz, and J. M. Navas, "Recovery of redox homeostasis altered by CuNPs in H4IIE liver cells does not reduce the cytotoxic effects of these NPs: an investigation using aryl hydrocarbon receptor (AhR) dependent antioxidant activity," Chemico-Biological Interactions, vol. 228, pp. 57-68, 2015.

[53] S. K. Niture and A. K. Jaiswal, "Nrf2 protein up-regulates antiapoptotic protein $\mathrm{Bcl}-2$ and prevents cellular apoptosis," The Journal of Biological Chemistry, vol. 287, pp. 9873-9886, 2012.

[54] L. Boquist, S. Boquist, and U. Alehagen, "Mitochondrial changes and associated alterations induced in mice by streptozotocin administered in vivo and in vitro," Diabetes Research and Clinical Practice, vol. 3, pp. 179-190, 1987.

[55] N. G. Morgan, H. C. Cable, N. R. Newcombe, and G. T. Williams, "Treatment of cultured pancreatic B-cells with streptozotocin induces cell death by apoptosis," Bioscience Reports, vol. 14, pp. 243-250, 1994.

[56] K. B. Koo, H. J. Suh, K. S. Ra, and J. W. Choi, "Protective effect of cyclo(his-pro) on streptozotocin-induced cytotoxicity and apoptosis in vitro," Journal of Microbiology and Biotechnology, vol. 21, pp. 218-227, 2011.

[57] W. S. Chen, X.-D. Peng, Y. Wang et al., "Leptin deficiency and beta-cell dysfunction underlie type 2 diabetes in compound Akt knockout mice," Molecular and Cellular Biology, vol. 29, p. 3151, 2009.

[58] H. K. Liu, J. T. McCluskey, N. H. McClenghan, and P. R. Flatt, "Streptozotocin-resistant BRIN-BD11 cells possess wide spectrum of toxin tolerance and enhanced insulin-secretory capacity," Endocrine, vol. 32, pp. 20-29, 2007.

[59] D. L. Eizirik and M. I. Darville, "Beta-cell apoptosis and defense mechanisms: lessons from type 1 diabetes," Diabetes, vol. 50, Supplement 1, pp. S64-S69, 2001.

[60] H. C. Lok, S. Sahni, P. J. Jansson, Z. Kovacevic, C. L. Hawkins, and D. R. Richardson, "A nitric oxide storage and transport system that protects activated macrophages from endogenous nitric oxide cytotoxicity," The Journal of Biological Chemistry, vol. 291, pp. 27042-27061, 2016. 


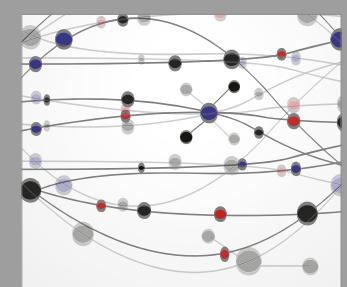

The Scientific World Journal
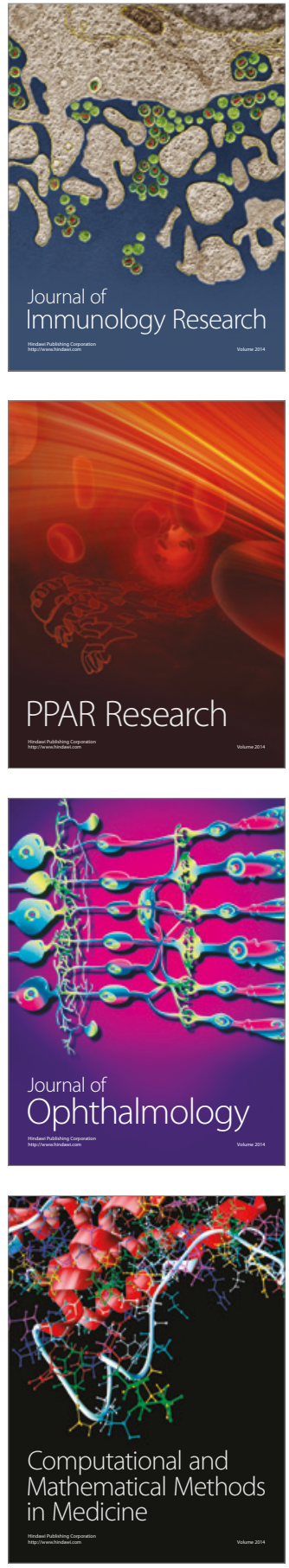

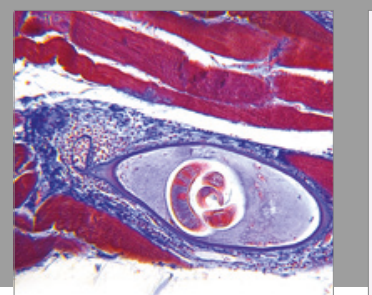

Gastroenterology Research and Practice
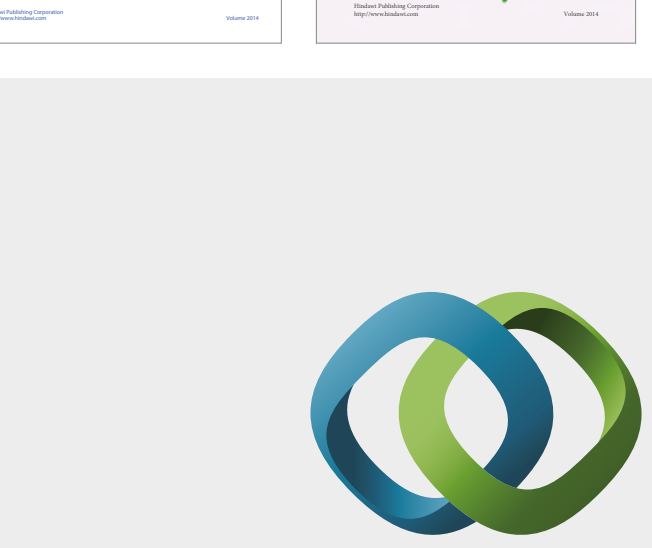

\section{Hindawi}

Submit your manuscripts at

https://www.hindawi.com
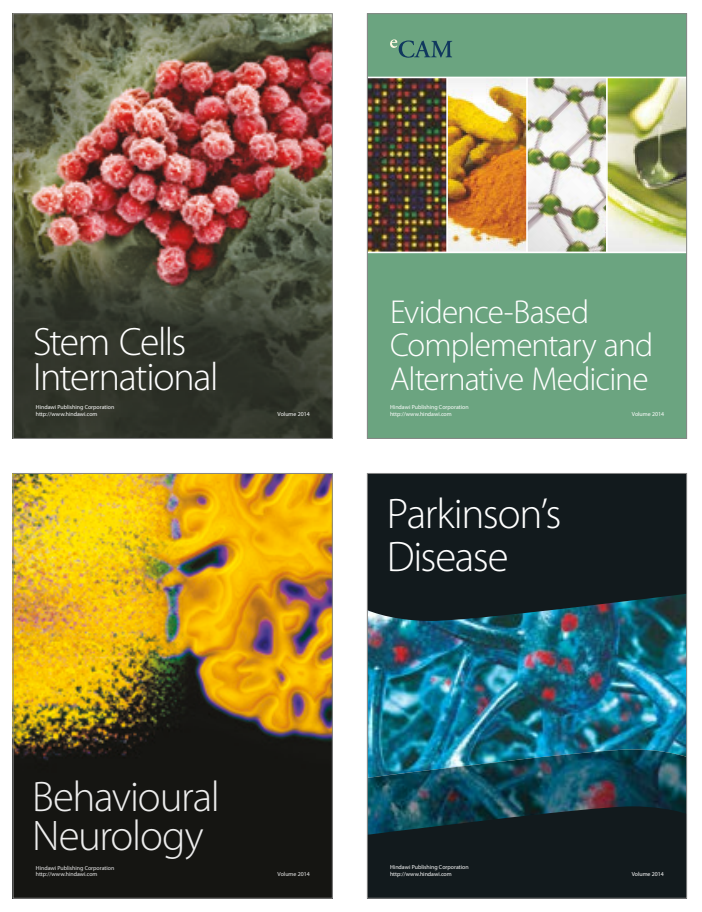
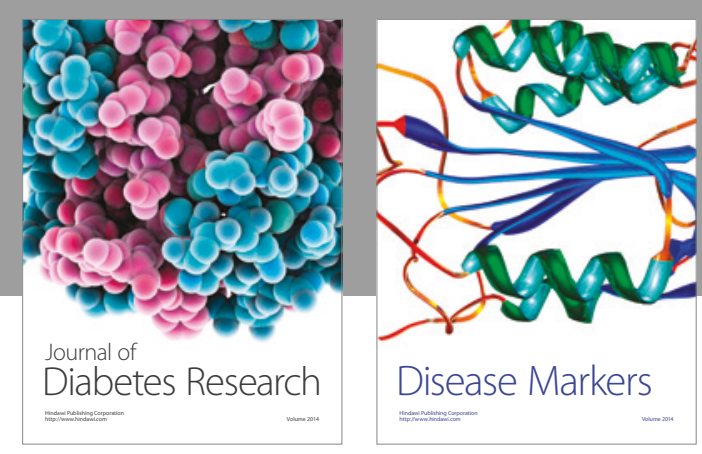

Disease Markers
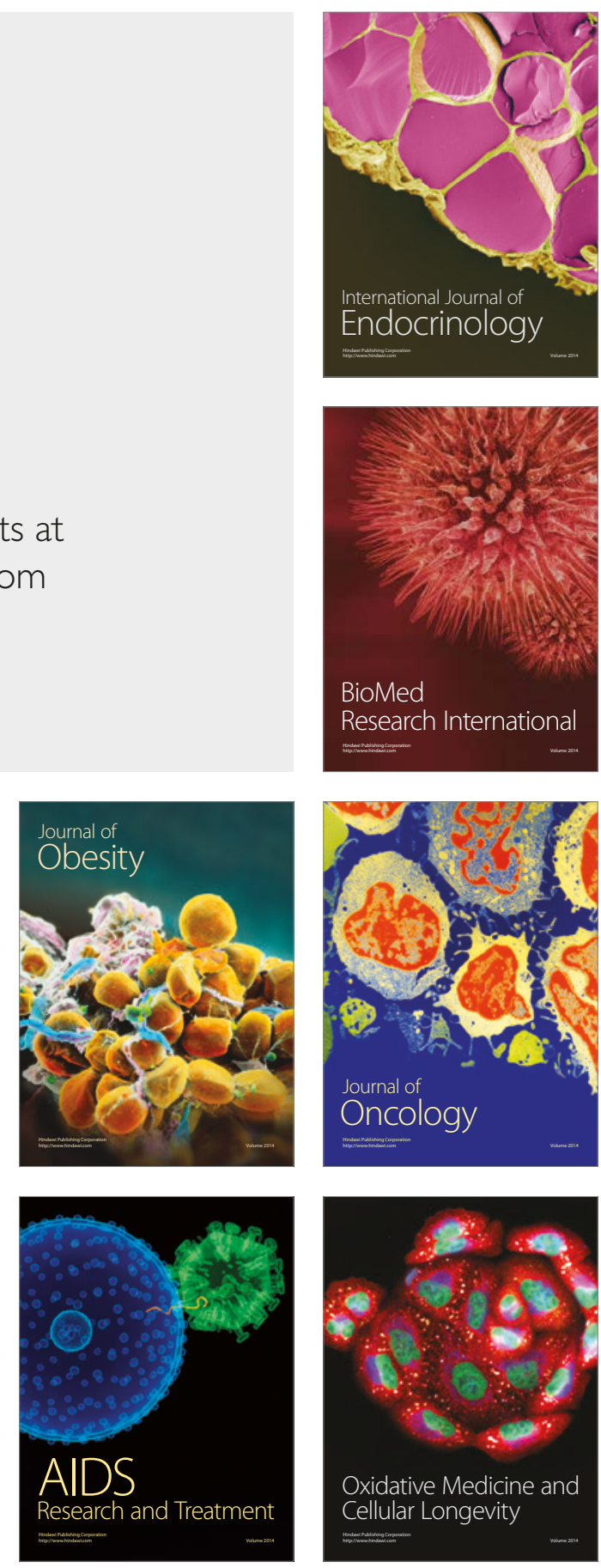